\title{
Electrochemically Reduced Water Protects Neural Cells from Oxidative Damage
}

\author{
Taichi Kashiwagi, ${ }^{1}$ Hanxu Yan, ${ }^{2}$ Takeki Hamasaki, ${ }^{2}$ Tomoya Kinjo, ${ }^{2}$ \\ Noboru Nakamichi, ${ }^{1}$ Kiichiro Teruya, ${ }^{1,2}$ Shigeru Kabayama, ${ }^{3}$ and Sanetaka Shirahata ${ }^{1,2}$ \\ ${ }^{1}$ Department of Bioscience and Biotechnology, Faculty of Agriculture, Kyushu University, Fukuoka 812-8581, Japan \\ ${ }^{2}$ Division of Life Engineering, Graduate School of Systems Life Sciences, Kyushu University, 6-10-1 Hakozaki, Higashi-ku, \\ Fukuoka 812-0053, Japan \\ ${ }^{3}$ Nihon Trim Co. LTD., 1-8-34 Oyodonaka, Kita-ku, Osaka 531-0076, Japan
}

Correspondence should be addressed to Sanetaka Shirahata; sirahata@grt.kyushu-u.ac.jp

Received 11 March 2014; Revised 19 August 2014; Accepted 2 September 2014; Published 14 October 2014

Academic Editor: Giles E. Hardingham

\begin{abstract}
Copyright (C) 2014 Taichi Kashiwagi et al. This is an open access article distributed under the Creative Commons Attribution License, which permits unrestricted use, distribution, and reproduction in any medium, provided the original work is properly cited.

Aging-related neurodegenerative disorders are closely associated with mitochondrial dysfunction and oxidative stresses and their incidence tends to increase with aging. Brain is the most vulnerable to reactive species generated by a higher rate of oxygen consumption and glucose utilization compared to other organs. Electrochemically reduced water (ERW) was demonstrated to scavenge reactive oxygen species (ROS) in several cell types. In the present study, the protective effect of ERW against hydrogen peroxide $\left(\mathrm{H}_{2} \mathrm{O}_{2}\right)$ and nitric oxide $(\mathrm{NO})$ was investigated in several rodent neuronal cell lines and primary cells. ERW was found to significantly suppress $\mathrm{H}_{2} \mathrm{O}_{2}(50-200 \mu \mathrm{M})$ induced PC12 and SFME cell deaths. ERW scavenged intracellular ROS and exhibited a protective effect against neuronal network damage caused by $200 \mu \mathrm{M} \mathrm{H}_{2} \mathrm{O}_{2}$ in N1E-115 cells. ERW significantly suppressed NO-induced cytotoxicity in PC12 cells despite the fact that it did not have the ability to scavenge intracellular NO. ERW significantly suppressed both glutamate induced $\mathrm{Ca}^{2+}$ influx and the resulting cytotoxicity in primary cells. These results collectively demonstrated for the first time that ERW protects several types of neuronal cells by scavenging ROS because of the presence of hydrogen and platinum nanoparticles dissolved in ERW.
\end{abstract}

\section{Introduction}

Living organisms inevitably live with the process of aging which has been closely linked as a critical causative factor for the development of neurodegenerative disorders (NDs) such as Alzheimer's disease (AD), Parkinson's disease (PD), Huntington's disease (HD), and Amyotrophic lateral sclerosis (ALS) [1-3]. Moreover, the development of agingrelated NDs has been shown to be closely associated with mitochondrial dysfunction and oxidative stresses $[1,4,5]$. Oxidative stress is a state where the cell is overwhelmed with reactive oxygen species (ROS) and reactive nitrogen species (RNS), resulting from an imbalance between reactive species production and detoxification $[3,6]$. Aerobic organisms absolutely require oxygen for the maintenance of normal physiological functions. In particular, the brain is responsible for more than $20 \%$ of total body oxygen consumption and $25 \%$ of total body glucose utilization although it represents less than $2 \%$ of the whole body weight [7]. Such high oxygen consumption in the brain consequently produces a large amount of reactive species compared to other organs in the body [6]. ROS include a variety of diverse chemical species such as superoxide anion $\left(\mathrm{O}_{2}{ }^{-}{ }^{-}\right)$, hydroxyl radical $\left({ }^{\circ} \mathrm{OH}\right)$, and hydrogen peroxide $\left(\mathrm{H}_{2} \mathrm{O}_{2}\right)$, all of which are capable of causing extensive oxidative damage to biological macromolecules like DNA, RNA, proteins, and lipids [810]. In addition, RNS such as nitric oxide (NO, an unstable free radical) is induced by glutamate, a neurotransmitter abundant in the central nervous system (CNS) and essential for proper neurological processes. However, NO in excess leads to pathological complications such as NDs. Accumulated data have shown that glutamate induces $\mathrm{Ca}^{2+}$ influx by 
way of the glutamate receptor channel, $\mathrm{N}$-methyl-D-aspartate (NMDA). The increased intracellular $\mathrm{Ca}^{2+}$ levels together with endogenous calmodulin stimulate nitric oxide synthase (NOS) to produce NO which is converted to neurodestructive $\mathrm{NO}$ radical $\left(\mathrm{NO}^{*}\right)$ depending on the redox conditions in the neuronal cells. $\mathrm{NO}^{*}$ further reacts with $\mathrm{O}_{2}{ }^{-{ }^{-}}$generating a potent oxidant, $\mathrm{ONOO}^{-}$. Thereafter, $\mathrm{ONOO}^{-}$is rapidly converted to highly reactive ${ }^{\circ} \mathrm{OH}$ which is cytotoxic $[2,10-$ 12]. Moreover, the damage is exasperated by the fact that the CNS contains a high amount of polyunsaturated fatty acids which are readily peroxidized by toxic reactive species [10] and has relatively low levels of antioxidative enzymes $[8,10]$. Therefore, such inherent characteristics of the CNS and the ROS and RNS individually or in combination contribute to the development of NDs. Antioxidants, metal chelators, or other agents that improve endogenous enzymatic and nonenzymatic cellular defense systems have been suggested as treatments for NDs [6]. Control of ROS production by mitochondrially targeted antioxidant treatment is expected to delay aging [1]. Antioxidant therapies using plant extracts from seeds and leaves are reported to be beneficial [13] while some other prospective substances have been tested with unsatisfactory results $[2,14]$. For antioxidant therapies to be effective, they must cross the blood brain barrier (BBB), which protects the brain from toxins and reduces the bioavailability of exogenous antioxidants in the brain $[2,6]$. Therefore, it is highly desirable to develop alternative agents that are able to pass through the BBB and exert antioxidative effects in the brain.

One promising candidate is electrochemically reduced water (ERW) because it has the potential to cross the BBB. ERW produced near the cathode during electrolysis of $2 \mathrm{mM}$ $\mathrm{NaOH}$ model water has characteristics of high $\mathrm{pH}$, low dissolved oxygen, and an extremely negative redox potential [15]. ERW contains a high concentration of dissolved hydrogen (0.4-0.9 ppm) and a small amount of platinum nanoparticles (Pt nps, 0.1-2.5 ppb), both of which exhibit ROS-scavenging ability [11, 16, 17]. Neutralized ERW has been shown to exhibit $\mathrm{H}_{2} \mathrm{O}_{2}$-scavenging activity which is correlated with protection of DNA $[18,19]$ and carbon tetrachloride induced liver damage [20], lifespan extension of Caenorhabditis elegans [16, 21], alloxan-induced type 1 diabetes $[15,19]$, hemodialysis-induced oxidative stress during end-stage renal disease $[22,23]$, and inhibitory effects of HT1080 tumor cell invasion [24]. ERW, in combination with glutathione, induced human leukemia HL-60 apoptotic cell death whereas a cytotoxic effect was not observed in normal peripheral blood mononuclear cells [25]. Despite the various protective functions exhibited by ERW, its effect on neuronal cells has not been disclosed in the literature other than in a brief meeting abstract by Yan et al. [26] who reported the protective effect of ERW on $\mathrm{H}_{2} \mathrm{O}_{2}$-induced cultured N1E-115 neuroblastoma cell death.

Cultures of nervous system tissues and cells are categorized in the terms of their complexities: whole-embryo, whole brain, organotypic slices, reaggregate cultures, dissociated primary cell cultures, and cell lines [27]. The degree of complexity of an in vitro model of dissociated primary cell cultures is considered to more closely reflect the in vivo state than that of the cell lines [27]. In light of this view, we also used mouse cerebral cortex neuronal primary (MCCNP) cells as a model to observe the effect of ERW in addition to immortalized cell lines. N1E-115 cells have been established as an adrenergic clone derived from mouse neuroblastoma C-300 [28] and are used as a model of CNS neurons [29-32]. In addition, in culture in the presence of several factors including DMSO, these cells display morphological characteristics of neuritogenesis which we used as a marker for changes upon treatment with ERW [33]. The PC12 cell line was established from a transplantable rat adrenal pheochromocytoma based on its response to nerve growth factor (NGF). PC12 cells possess the potential to be differentiated into either chromaffin cells or sympathetic neurons when in the presence of NGF [34]. This cell line has been used as a model for studying the neuronal response to oxidative stress [35-37]. Also, the viability of PC12 cells is described to be sensitive to NO stress, thus this makes them useful for detecting a subtle NO effect [38]. Serum-free mouse embryo (SFME) cells were established from mouse embryo cells by maintenance in the absence of serum [39]. These cells show the characteristics of an astrocyte, a progenitor cell without senescence which is the most abundant cell type in the CNS $[39,40]$.

In the present study, we utilized various cell types originating from mouse and rat as a first step to explore the protective effect of ERW on neurocytotoxicity caused by reactive species.

\section{Materials and Methods}

2.1. Materials. Dulbecco's Modified Eagle's Medium (DMEM) and DMEM/Ham's F12 Combined Medium ( $1: 1)$ were purchased from Nissui Pharmaceutical Co., LTD. (Tokyo, Japan). Insulin, putrescine, transferrin, propidium iodide (PI), Fluo-3/AM, pluronic F127, sodium glutamate, and $\mathrm{Ca} 2+, \mathrm{Mg} 2+-$ free Hank's balanced salt solution (Ca2+, $\mathrm{Mg} 2+$-free HBSS) were purchased from Sigma-Aldrich Japan (Tokyo, Japan). 2I, 7I-Dichlorofluorescin diacetate (DCFHDA) was purchased from Invitrogen Technologies (Carlsbad, CA, USA). Chemically defined lipid (CDL) and mouse epidermal growth factor (mEGF) were purchased from Life Technologies Japan (Tokyo, Japan). Cell counting kit- 8 (CCK-8) which uses WST-8 as a color indicator to measure live cell numbers was purchased from Dojindo Laboratories Co. (Tokyo, Japan) and the kit is referred to as the WST-8 kit hereafter. Diaminorhodamine-4M acetoxymethyl ester (DAR-4M AM) was from Daiichi Pure Chemicals Co., LTD. (Tokyo, Japan). N-Acetyl-L-cysteine (L-NAC), ascorbic acid (AsA), sodium nitroprusside (SNP), 4-[2-hydroxyethyl]1-piperazineethane-sulfonic acid (HEPES), fetal bovine serum (FBS), bovine serum albumin (BSA), penicillin, streptomycin, progesterone, and all other chemicals were obtained from Wako Pure Chemical Industries, LTD. (Osaka, Japan). The gelatin sepharose $4 \mathrm{~B}$ column was obtained from GE Healthcare Japan (Tokyo, Japan). Ultrapure water 
(MQ-water) was produced by a Millipore filtration system (Billerica, MA, USA).

2.2. Preparation of ERW. ERW was prepared by electrolysis of MQ-water containing $2 \mathrm{mM} \mathrm{NaOH}$ at $100 \mathrm{~V}$ for $60 \mathrm{~min}$ using a TI-200 electrolysis device (Nihon Trim Co., Osaka, Japan). The device is a batch-type system composed of a 4-liter electrolysis vessel which is divided into two compartments by a semipermeable membrane. Each compartment contains a platinum-coated titanium (Ti) electrode. Further details of the device and the characteristics of ERW including $\mathrm{pH}$, dissolved hydrogen/oxygen and Pt nanoparticle concentrations, and redox potential are given in our previous reports $[15,16$, 41]. ERW was neutralized with HEPES buffer or bicarbonate buffer in medium before use. $\mathrm{NaOH}$ solution was adjusted to the same $\mathrm{pH}$ with that of freshly prepared ERW and used as control water.

2.3. Preparation of Cell Culture Medium. 5x DMEM/Ham's F12 medium (1:1 mixture of 5x DMEM and 5x Ham's F12 medium, no FBS) was diluted by quadruple neutralized ERW or MQ-water as the control to make the control medium. Normal DMEM/F12 medium supplemented with different concentrations of L-NAC or AsA was used as positive controls in this study.

2.4. Cell Cultures. Murine neuroblastoma N1E-115 cells were purchased from ATCC (VA, USA) and maintained in $90 \%$ DMEM/Ham's F12 medium supplemented with 10\% FBS, $2 \mathrm{mM}$ glutamine, $100 \mathrm{U} / \mathrm{mL}$ penicillin, and $100 \mu \mathrm{g} / \mathrm{mL}$ streptomycin and incubated in a humidified atmosphere of $5 \%$ $\mathrm{CO}_{2}$ at $37^{\circ} \mathrm{C}$. For differentiation, a previously published method was followed with modifications [31]. N1E-115 cells were cultured in $88 \%$ DMEM/Ham's F12 medium containing $10 \% \mathrm{FBS}, 2 \%$ dimethyl sulfoxide (DMSO) in poly-D-lysine (PDL)-coated dishes for 6 days, and then the medium was replaced with serum-free DMEM/F12 medium supplemented with $5 \mu \mathrm{g} / \mathrm{mL}$ insulin, $100 \mu \mathrm{M}$ putrescine, $20 \mathrm{nM}$ progesterone, and $5 \mu \mathrm{g} / \mathrm{mL}$ transferrin. Rat pheochromocytoma PC12 cells were purchased from RIKEN Cell Bank (Tsukuba, Japan). Cells were cultured in DMEM containing $5 \%$ horse serum (HS), $5 \%$ fetal bovine serum (FBS), $100 \mathrm{U} / \mathrm{mL}$ penicillin, and $100 \mu \mathrm{g} / \mathrm{mL}$ streptomycin and incubated in a humidified atmosphere of $5 \% \mathrm{CO}_{2}$ at $37^{\circ} \mathrm{C}$. Medium was changed every 2 days. Differentiation into neuronal cells was carried out by culturing in PDL-coated dishes containing DMEM supplemented with $0.5 \% \mathrm{HS}, 0.5 \% \mathrm{FBS}$, and $20 \mathrm{nM}$ nerve growth factor (NGF) for 4 days in a humidified atmosphere of $5 \% \mathrm{CO}_{2}$ at $37^{\circ} \mathrm{C}$. Serum-free mouse embryo (SFME) cells were kindly provided by Loo et al. [39] and cultured in a 1:1 mixture of DMEM: Ham's F12 medium containing 10 $\mathrm{nM}$ sodium selenite, $1.2 \mathrm{~g} / \mathrm{L}$ sodium bicarbonate, $10 \mu \mathrm{g} / \mathrm{mL}$ transferrin, $1 \%$ of CDL, and $50 \mathrm{ng} / \mathrm{mL}$ mEGF in fibronectincoated $25 \mathrm{~cm}^{2}$ T-flasks. Fibronectin was purified from BSA using a gelatin sepharose $4 \mathrm{~B}$ column by the published method [42].
2.5. Preparation of Mouse Cerebral Cortex Neuronal Primary (MCCNP) Cells. MCCNP cells were prepared from the cerebral cortex of fetal mouse (15-16 days gestation) that has been removed aseptically from an anesthetized and decapitated mouse (ddy strain, Asekku-Yoshitomi Co. Fukuoka, Japan). The embryos were removed under sterile conditions and placed into an ice-cold 1:1 mixture of phosphate-buffered saline (PBS) and DMEM. Cerebral cortex excised from the brain was minced and incubated for $15 \mathrm{~min}$ in a mixture of $0.05 \%$ trypsin and PBS. Single cells dissociated from the cerebral cortex were counted, adjusted to $0.5-1.0 \times 10^{5}$ cells $/ \mathrm{mL}$, with DMEM supplemented with 5\% HS, 5\% FBS, $100 \mathrm{U} / \mathrm{mL}$ penicillin, and $100 \mu \mathrm{g} / \mathrm{mL}$ streptomycin, and seeded on PDLcoated 24-well plastic plates. Cells were incubated for 2 days in a humidified atmosphere of $5 \% \mathrm{CO}_{2}$ at $37^{\circ} \mathrm{C}$. After the incubation, $10 \mu \mathrm{M}$ cytosine $\beta$-D-arabinofuranoside hydrochloride (Ara-C), a deoxyribonucleic acid synthesis inhibitor, was added and the cells were incubated for further $24 \mathrm{~h}$ to eliminate rapidly growing nonneuronal cells $[43,44]$. Ara-C containing medium was replaced with DMEM growth medium as described above, and the cells were incubated for 7 to 10 days prior to subsequent experiments.

2.6. Animal Handling. Mice were handled with care following the guidelines for Animal Experiments provided by the Faculty of Agriculture and the Graduate School of Kyushu University and the Law (No. 105) and Notification (No. 6) of the Government.

2.7. Cell Viability Assay. A WST-8 kit was used to obtain a viable cell count (Dojindo Co., Tokyo, Japan). The assay protocol provided by the manufacturer was closely followed. Briefly, N1E115 cells $\left(10^{4}\right.$ cells/well) were seeded in a PDLcoated 24-well plate and pr-incubated with FBS/DMEM medium. Following cell differentiation with DMSO, cells were treated with serum-free medium made of MQ-water, ERW, L-NAC, AsA, or $2 \mathrm{mM} \mathrm{NaOH}$ supplemented with or without different concentrations of $\mathrm{H}_{2} \mathrm{O}_{2}$ for $24 \mathrm{~h}$. To each well, $1 \mu \mathrm{L}$ of WST- 8 dye was added and incubation was continued for further $4 \mathrm{~h}$. Viable cells were measured at $450 \mathrm{~nm}$ using a microtiter plate reader (Lancraft, Inc., Norcross, GA, USA). PC12 cells ( $10^{4}$ cells/well) were seeded in PDL-coated 24-well plates and preincubated in FBS/HS/DMEM medium. Differentiation was accomplished by adding NGF followed by a 4 day incubation (detail is given in the cell culture section). When cells were differentiated, they were treated with serum-free medium containing ERW with or without different concentrations of $\mathrm{H}_{2} \mathrm{O}_{2}$ or SNP for $24 \mathrm{~h}$. Viable cells were measured as described above. SFME cells ( $10^{5}$ cells/well) were seeded in 24-well plates and incubated in the presence of FBS/HS/DMEM medium for 1 day. Cells were treated with serum-free medium containing ERW with or without different concentrations of $\mathrm{H}_{2} \mathrm{O}_{2}$ for $24 \mathrm{~h}$ (detail is given in the cell culture section). Viable cells were measured as described above.

2.8. Intracellular $\mathrm{H}_{2} \mathrm{O}_{2}$ Detection Using a DCFH-DA Probe. $2^{\prime}, 7^{\prime}$-Dichlorofluorescin diacetate (DCFH-DA) can diffuse 
into cells where it is hydrolyzed by intracellular esterases resulting in the formation of DCFH. Then, DCFH is oxidized by intracellular oxidizing species including $\mathrm{H}_{2} \mathrm{O}_{2}$ to form the highly fluorescent product, $2^{\prime}, 7^{\prime}$-dichlorofluorescin (DCF), which can be detected by appropriate devices such as a flow cytometer and/or confocal laser microscope. DCFH-DA has been shown to be useful to estimate intracellular $\mathrm{H}_{2} \mathrm{O}_{2}$ in rat neuron cells [45].

2.9. Flow Cytometric Analysis of Intracellular $\mathrm{H}_{2} \mathrm{O}_{2}$. N1E-115 cells $\left(7.5 \times 10^{4}\right.$ cells) were seeded in an uncoated $10 \mathrm{~cm}$ dish and precultured for 1 day. Then, the medium was replaced with HBSS (137 mM NaCl, $5 \mathrm{mM} \mathrm{KCl}, 1 \mathrm{mM} \mathrm{Na} \mathrm{HPO}_{4}, 5 \mathrm{mM}$ glucose, $1 \mathrm{mM} \mathrm{CaCl}, 0.5 \mathrm{mM} \mathrm{MgCl}_{2}, 1 \mathrm{mg} / \mathrm{mL} \mathrm{BSA}$, and 10 mM HEPES, pH 7.4) buffer containing ERW, L-NAC (0.1, $1.0 \mathrm{mM})$, AsA (0.1, 1.0 mM), or control MQ-water and was incubated for $10 \mathrm{~min}$. After removing the supernatant, $2 \mathrm{~mL}$ of $5 \mu \mathrm{M}$ DCFH-DA, in $\mathrm{Ca}^{2+}, \mathrm{Mg}^{2+}$-free HBSS, adjusted $\mathrm{pH}$ to 7.4 with $10 \mathrm{mM}$ HEPES buffer, was added to the dish and incubated for further $15 \mathrm{~min}$. Cells were then harvested in $5 \mathrm{~mL}$ of PBS buffer and collected by centrifugation at $500 \times \mathrm{g}$ for $3 \mathrm{~min}$ and then resuspended in $1 \mathrm{~mL}$ of PBS. Fluorescence intensities were measured immediately using an EPICS XL System II-JK flow cytometer (Beckman Coulter, Miami, USA), with excitation and emission wavelengths of 495 and $525 \mathrm{~nm}$, respectively. Histograms were analyzed by using FlowJo software supplied with the cytometer.

2.10. Confocal Laser Microscopic Analysis of Intracellular $\mathrm{H}_{2} \mathrm{O}_{2}$. The intracellular $\mathrm{H}_{2} \mathrm{O}_{2}$ was visualized using the DCFH-DA probe. One milliliter of N1E115 cells $(2 \times$ $10^{4}$ cells $/ \mathrm{mL}$ ) was precultured in a $35 \mathrm{~mm}$ dish for 1 day. Then, the medium was replaced with HBSS made with ERW or control MQ-water, with or without $200 \mu \mathrm{M}$ of $\mathrm{H}_{2} \mathrm{O}_{2}$, and incubated for $10 \mathrm{~min}$. After removing the supernatant, $2 \mathrm{~mL}$ of $5 \mu \mathrm{M}$ DCFH-DA in $\mathrm{Ca}^{2+}, \mathrm{Mg}^{2+}$-free HBSS, adjusted to $\mathrm{pH}$ 7.4 with $10 \mathrm{mM}$ HEPES buffer, was added and the dish was incubated for further $10 \mathrm{~min}$. Cells were then washed with HBSS to remove unreacted DCFH-DA and the cytoplasmic fluorescence intensities were measured using a confocal laser scanning microscope (Molecular Dynamics, Sunnyvale, CA, USA) with a FITC barrier filter at excitation and emission wavelengths of 488 and $530 \mathrm{~nm}$, respectively.

2.11. Assessment of Nitric Oxide (NO) Toxicity Using a Cell Viability Assay. Differentiated PC12 cells were cultured in a medium made of ERW or MQ-water each containing 0, 200, 400, or $600 \mu \mathrm{M}$ sodium nitroprusside (SNP) for $24 \mathrm{~h}$. The viability of the cells was measured using the WST- 8 kit method.

2.12. Detection of Intracellular NO. Intracellular NO in the cells can be detected using a rhodamine chromophore, the DAR-4M AM NO bioimaging probe. DAR-4M AM diffuses into cells and is hydrolyzed by intracellular esterases resulting in the formation of membrane impermeable DAR-4M. DAR$4 \mathrm{M}$ then reacts with $\mathrm{NO}$ in the presence of oxygen forming a fluorescent triazol compound, DAR-4M T, which can be visualized using a fluorescence microscope at $560 \mathrm{~nm}$ excitation and $575 \mathrm{~nm}$ emission [46]. For PC12 cells, $2 \times$ $10^{5}$ cells were seeded in a $35 \mathrm{~mm}$ dish and incubated for 1 day. Cells were then treated with the medium made of ERW or MQ-water each containing $200 \mu \mathrm{M}$ SNP for $20 \mathrm{~min}$. Following the incubation period, cells were washed once with HBSS and $10 \mu \mathrm{M}$ DAR-4M AM in HBSS was added and the cells were incubated for $30 \mathrm{~min}$. The cells were washed once with HBSS and intracellular fluorescence was observed using a fluorescence microscope (IX70, Olympus, Japan) and was photographed.

2.13. Measurement of Intracellular $\mathrm{Ca}^{2+}$. Intracellular $\mathrm{Ca}^{2+}$ was measured using Fluo-3 AM, a membrane-permeable calcium sensitive dye. Internalized Fluo-3 AM is hydrolyzed by intracellular esterases liberating Flou-3 which can react with intracellular free $\mathrm{Ca}^{2+}$ ions to form a fluorescent complex. After pretreatment with glutamate $(0,0.1$ or $1.0 \mathrm{mM})$ in medium made of ERW or MQ-water for $10 \mathrm{~min}, \mathrm{PMN}$ cells were stained with $300 \mu \mathrm{L}$ of dye mixture composed of $4 \mu \mathrm{M}$ Fluo-3 AM and $0.8 \mathrm{mg} / \mathrm{mL}$ pluronic F127 in HBSS, $\mathrm{pH}$ 7.4 for $20 \mathrm{~min}$, and then $1 \mathrm{~mL}$ of $1 \%$ FBS containing HBSS was added followed by a further $40 \mathrm{~min}$ incubation [47]. Cells were washed once with HBSS and suspended in $1 \mathrm{~mL}$ HEPES buffer. A fluorescence microscope was used to detect intracellular fluorescence and the images were recorded by a digital camera. Digital images were converted to a numerical readout with the aid of a NIH image analysis program and then were analyzed by Excel software.

2.14. Measurement of Glutamate Neurotoxicity. Glutamate toxicity was measured using PMN cells. After cells were treated with $0,0.1$, and $0.5 \mathrm{mM}$ glutamate in the medium made of ERW or MQ-water for $24 \mathrm{~h}$, nonviable cells were detected using trypan blue dye which does not enter live cells because of their intact cell membranes. Treated cells were stained with $0.1 \%$ trypan blue for $10 \mathrm{~min}$, fixed with $4 \%$ paraformaldehyde for $15 \mathrm{~min}$ at $4^{\circ} \mathrm{C}$, and rinsed once with PBS. The nonviable cells stained blue by the dye were counted in 8 randomly selected fields as one set and 4 sets for each treatment were counted under the microscope (CK2, Olympus, Japan).

2.15. Statistical Analysis. Three to four independent experiments were performed. Data are presented as the mean \pm standard deviation (SD). Statistical significance was determined by repeated measures analysis of variance with post hoc comparisons using the Tukey test and a $P$ value of $<0.05$ was considered significant.

\section{Results}

3.1. ERW Protects Neural Cells From $\mathrm{H}_{2} \mathrm{O}_{2}$-Induced Cell Death. ERW has been reported to suppress $\mathrm{H}_{2} \mathrm{O}_{2}$-induced oxidative stress in neuroblastoma N1E115 cells [26]. We first examined whether $\mathrm{H}_{2} \mathrm{O}_{2}$-induced oxidative stress was suppressed by ERW in two other neuronal cell lines, PC-12 and SFME. Because PC12 and SFME cells showed different 
sensitivity to $\mathrm{H}_{2} \mathrm{O}_{2}$ in terms of cell viability, different $\mathrm{H}_{2} \mathrm{O}_{2}$ concentrations were tested in the present studies (data not shown). Differentiated PC12 cells were treated for $24 \mathrm{~h}$ with $0,100,200$, or $500 \mu \mathrm{M} \mathrm{H}_{2} \mathrm{O}_{2}$ with or without ERW. ERW significantly suppressed cell death when treated with 100 or $200 \mu \mathrm{M} \mathrm{H}_{2} \mathrm{O}_{2}$ (Figure $1(\mathrm{a}),{ }^{*} P<0.05$ ) but not with $500 \mu \mathrm{M}$ $\mathrm{H}_{2} \mathrm{O}_{2}$. SFME cells were treated for $24 \mathrm{~h}$ with $0,50,100$, or $200 \mu \mathrm{M} \mathrm{H}_{2} \mathrm{O}_{2}$ with or without ERW. ERW significantly suppressed cell death when treated with 50 or $100 \mu \mathrm{M} \mathrm{H}_{2} \mathrm{O}_{2}$ (Figure 1(b), ${ }^{*} P<0.05$ ) but not with $200 \mu \mathrm{M} \mathrm{H}_{2} \mathrm{O}_{2}$. When these cell lines were treated with ERW alone $\left(0 \mu \mathrm{M} \mathrm{H}_{2} \mathrm{O}_{2}\right)$ the number of viable cells did not increase compared to that of the controls (Figures 1(a) and 1(b)). Therefore, the results indicate that ERW suppresses neuronal cell death caused by $\mathrm{H}_{2} \mathrm{O}_{2}$-induced oxidative damage.

3.2. ERW and Antioxidants Protect Neuronal Cells from $\mathrm{H}_{2} \mathrm{O}_{2}$ Induced Cell Death. We decided to further confirm ERW efficacy by using the known antioxidants, L-NAC and AsA as system controls. The cell viability for the absolute control was set as $100 \%$ (Figure 2 ). The cell viability for the positive control was reduced to $60 \%$ compared to the absolute control (Figure 2). When the N1E-115 cells were cultured with the medium made of ERW containing $200 \mu \mathrm{M} \mathrm{H} \mathrm{H}_{2} \mathrm{O}_{2}$, the cell viability was significantly increased compared to the positive control (Figure 2, ${ }^{*} P<0.05$ ) in agreement with the previous result [26]. We also found that autoclaved ERW was not protective against $200 \mu \mathrm{M} \mathrm{H}_{2} \mathrm{O}_{2}$ induced cell death (Figure 2). When N1E-115 cells were cultured with the positive control medium supplemented with the known antioxidants, $1 \mathrm{mM}$ L-NAC or $1 \mathrm{mM}$ AsA, the viability increased significantly, compared with the positive control, respectively (Figure $2,{ }^{*} P<0.05,{ }^{* *} P<0.01$ ), and indicated the assay system was working properly. Cell viability was not affected when the cells were cultured with the positive control medium supplemented with $0.1 \mathrm{mM}$ L-NAC or AsA or $2 \mathrm{mM}$ $\mathrm{NaOH}$ (Figure 2). From the results, ERW was confirmed to exert protective effects against $\mathrm{H}_{2} \mathrm{O}_{2}$ induced cell death.

3.3. ERW Maintains Differentiated Morphology against $\mathrm{H}_{2} \mathrm{O}_{2}$ Induced Oxidative Stress. We next tested whether ERW affects N1E-115 cell morphology. Undifferentiated cells exhibited a typical round shaped morphology (Figure 3(a)) while differentiated cells showed a neuronal network representing neurite outgrowth (Figures 3(b) and 3(d)). These cellular morphologies are quite similar to those of published data [33]. When the differentiated cells were cultured in the medium made of MQ-water containing $200 \mu \mathrm{M} \mathrm{H}_{2} \mathrm{O}_{2}$, the neuronal network disappeared (Figure 3(c)) while the cells cultured with the medium made of ERW containing $200 \mu \mathrm{M} \mathrm{H}_{2} \mathrm{O}_{2}$ maintained the original state of differentiated morphology displaying a neuronal network and neurite outgrowth (Figure 3(e)). These results demonstrated that ERW is capable of maintaining the morphological integrity of differentiated neuronal cells against $\mathrm{H}_{2} \mathrm{O}_{2}$-induced oxidative stress.

3.4. ERW Scavenges Intracellular ROS. The results obtained thus far demonstrated the substantial protective effects of
ERW on N1E-115 cells against $\mathrm{H}_{2} \mathrm{O}_{2}$-induced cell death. We examined whether ERW is protecting cell death by scavenging intrinsic intracellular ROS. The intracellular $\mathrm{H}_{2} \mathrm{O}_{2}$ level of the N1E-115 cells treated for 10 min with ERW (mean value $=56.0$ ) was substantially decreased compared with the MQ-water control (mean value $=105.0)$ (Figure 4(a)). The intracellular $\mathrm{H}_{2} \mathrm{O}_{2}$ level of the cells treated for $24 \mathrm{~h}$ with the ERW (mean value $=61.7$ ) decreased to a lesser degree from the MQ-water control (mean value $=77.9$ ) (Figure 4(b)). When the N1E-115 cells were treated for $10 \mathrm{~min}$ with the medium containing $1 \mathrm{mM}$ L-NAC or AsA, the leftward shift indicative of the intracellular $\mathrm{H}_{2} \mathrm{O}_{2}$ scavenging was small but clearly recognizable (Figures $4(\mathrm{c})$ and $4(\mathrm{e})$ ). While the intracellular $\mathrm{H}_{2} \mathrm{O}_{2}$ level of $1 \mathrm{mM}$ L-NAC treated cells for 24 $\mathrm{h}$ was substantially reduced compared to MQ-water control (Figure $4(\mathrm{~d})$ ), the scavenging effect of $1 \mathrm{mM}$ AsA was evident but to a lesser extent (Figure 4(f)). Although the same experiment was performed with $0.1 \mathrm{mM}$ of L-NAC and AsA, this concentration did not show an appreciable scavenging effect after either $10 \mathrm{~min}$ or $24 \mathrm{~h}$ treatment (data not shown). From these results, ERW was shown to scavenge intracellular $\mathrm{H}_{2} \mathrm{O}_{2}$ within a short time, while the scavenging capabilities of AsA, in particular L-NAC, are exerted for at least 24 hours.

To confirm the flow cytometric data, we further tested the scavenging ability of ERW against induced intracellular $\mathrm{H}_{2} \mathrm{O}_{2}$ by using a combination of a DCFH-DA probe and a confocal microscope. Fluorescence intensities reflecting intracellular $\mathrm{H}_{2} \mathrm{O}_{2}$ levels obtained from the cells treated for $10 \mathrm{~min}$ with MQ-water alone (control) were set to $100 \%$ (Figures 5(e) and $5(\mathrm{a})$ ). When cells were treated for $10 \mathrm{~min}$ with ERW alone, the fluorescence intensity was decreased approximately $30 \%$ compared with that of the MQ-water control (Figures 5(e) and 5(b), $\left.{ }^{*} P<0.05\right)$. When the cells were cultured with the medium made of MQ-water containing $100 \mu \mathrm{M} \mathrm{H}_{2} \mathrm{O}_{2}$, the intracellular $\mathrm{H}_{2} \mathrm{O}_{2}$ level was increased by approximately $20 \%$ compared with that of the MQ-water control (Figures 5(e) and 5(c)). When the cells were cultured with the medium made of ERW containing $100 \mu \mathrm{M} \mathrm{H}_{2} \mathrm{O}_{2}$, the intracellular $\mathrm{H}_{2} \mathrm{O}_{2}$ level was suppressed approximately $20 \%$ compared with that of the MQ-water containing $100 \mu \mathrm{M} \mathrm{H}_{2} \mathrm{O}_{2}$ (Figures 5(e) and 5(d), $\left.{ }^{*} P<0.05\right)$. Representative images of 3 independent experiments are shown in Figures 5(a)-5(d). These images were used to generate Figure 5(e) by measuring the fluorescence intensities of each treatment. The same conclusion, ERW scavenges physiologically intrinsic $\mathrm{H}_{2} \mathrm{O}_{2}$ and exogenously induced $\mathrm{H}_{2} \mathrm{O}_{2}$, was reached from two independent detection methods.

3.5. Suppressive Effect of ERW on Nitric Oxide (NO) Toxicity in PC12 Cells. In the MQ-water control medium, SNP reduced $\mathrm{PC} 12$ cell viability in a manner approximating dose-dependency (Figure 6(a)). However, when cultured in the medium made of ERW, the cell viability was restored significantly, compared with the respective controls at 200 and $400 \mu \mathrm{M}$ SNP (Figure 6(a), ${ }^{*} P<0.05$ ). Thus, ERW could restore cell viability against $\mathrm{NO}$ generated by up to $400 \mu \mathrm{M}$ SNP. However, this finding does not prove that ERW is directly scavenging NO. To clarify this point, we assessed 


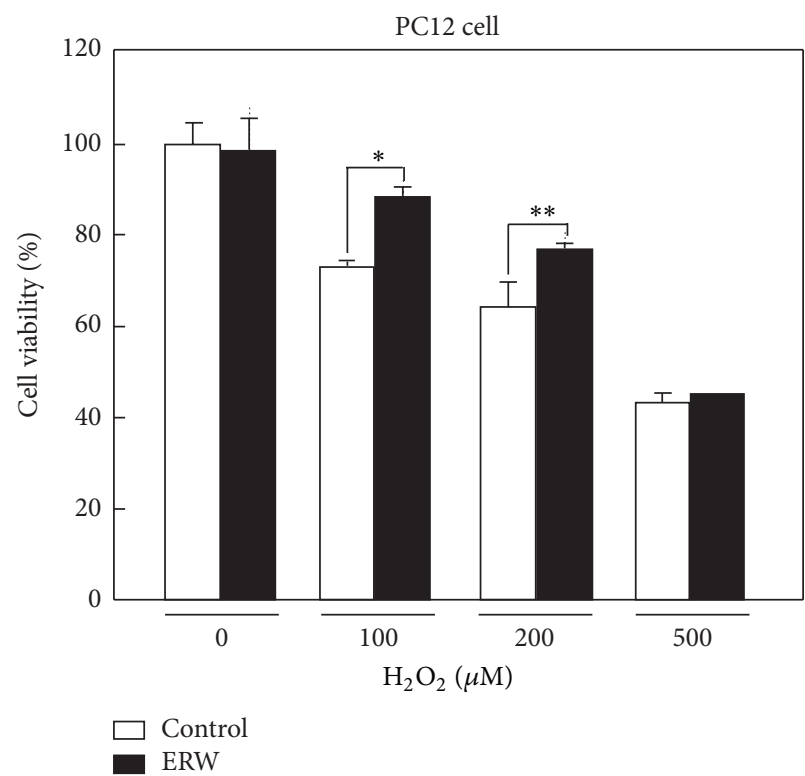

(a)

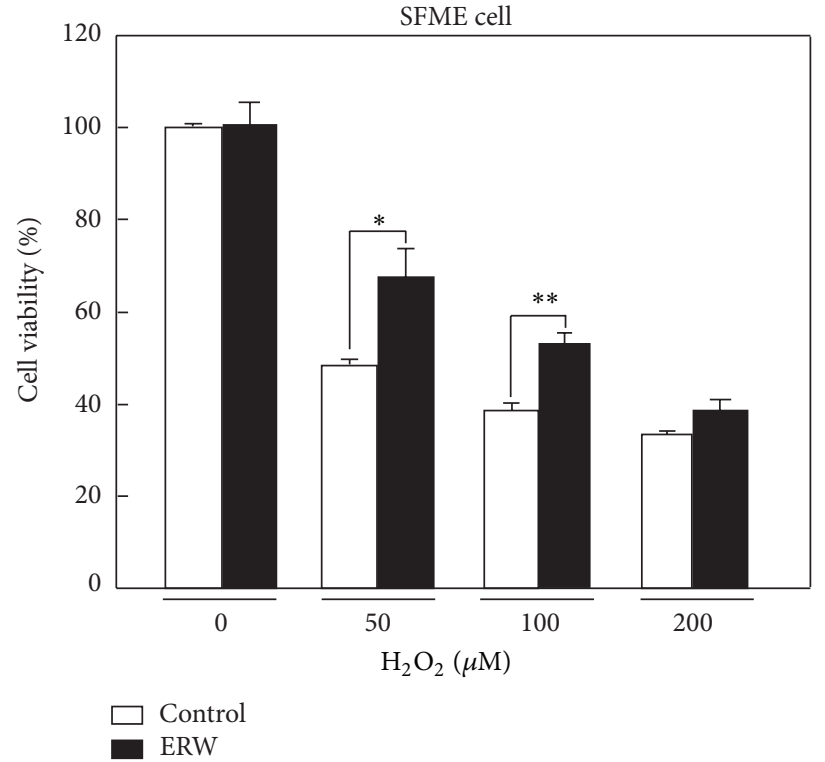

(b)

FIGURE 1: Suppressive effect of ERW against $\mathrm{H}_{2} \mathrm{O}_{2}$-induced cytotoxicity on PC12 and SFME cells. Viable cell numbers were measured using a WST-8 kit. (a) Pheochromocytoma PC12 cells were cultured in FBS/HS/DMEM medium with or without ERW and the number of surviving cells were set as controls. $\mathrm{H}_{2} \mathrm{O}_{2}(100,200$ and $500 \mu \mathrm{M})$ was added to the control medium and it was cultured for $24 \mathrm{~h}$. Viable cells were measured at $450 \mathrm{~nm}$ using a microtiter plate reader. (b) Serum-free mouse embryo (SFME) cells were cultured in a 1:1 mixture of DMEM: Ham's F12 medium with or without ERW and the number of surviving cells were set as controls. To the control medium, $\mathrm{H}_{2} \mathrm{O}_{2}(50,100$ and $200 \mu \mathrm{M})$ was added and it was cultured for $24 \mathrm{~h}$. Viable cells were measured at $450 \mathrm{~nm}$ using a microtiter plate reader. Data are presented as mean \pm standard deviation (SD) for three independent experiments $\left(n=3\right.$ each set). ${ }^{*} P<0.05$ and ${ }^{* *} P<0.01$.

the intracellular NO level directly using the NO-specific DAR-4M AM probe. Differentiated PC12 cells were treated with the medium made of ERW or MQ-water with or without $200 \mu \mathrm{M}$ SNP. After the SNP treatments, NO-induced DAR$4 \mathrm{M}$ intracellular fluorescence was observed by a fluorescence microscope and photographed (Figure 6(b)). Intracellular fluorescence was barely visible in the cells cultured with the medium made of either MQ-water or ERW (Figure 6(b), left side panels designated as MQ and ERW). Intracellular red fluorescence indicative of SNP induced NO was evident in the cells cultured with the medium made of MQ-water and ERW (Figure 6(b), right side panels designated as MQ + $200 \mu \mathrm{M}$ SNP and ERW $+200 \mu \mathrm{M}$ SNP). Using two of the right side panels, the fluorescence intensities were scored for 50 cells randomly picked in each panel. Analysis revealed no statistically significant differences between MQ- and ERWtreated cells (Figure 6(c)). Thus, ERW was found to lack direct NO scavenging activity in PC12 cells.

3.6. Suppressive Effect of ERW on Glutamate-Induced $\mathrm{Ca}^{2+}$ Influx and Cell Death. We used MCCNP cells to examine whether ERW can affect $\mathrm{Ca}^{2+}$ influx. As shown in Figure 7, the MQ-water control (red line) treated cells showed a new $\mathrm{Ca}^{2+}$ peak as indicated by a downward arrow in the 0.1 and $1 \mathrm{mM}$ glutamate treated cells compared with the $0 \mathrm{mM}$ glutamate treated cells. ERW (black line) in the presence of $0.1 \mathrm{mM}$ glutamate treated cells did not show such a peak indicative of $\mathrm{Ca}^{2+}$ influx. Even though the $1 \mathrm{mM}$ glutamate treated cells cultured in the presence of ERW showed a peak, the calcium concentration $\left[\mathrm{Ca}^{2+}\right]_{i}$ is less than that of the control. The results indicate that ERW suppresses glutamate induced $\mathrm{Ca}^{2+}$ influx in the MCCNPcells which suggests a reduction of cell death. This possibility was further tested using the trypan blue exclusion assay. As shown in Figure 8(b), dead cells treated with the medium made of the MQwater control with 0.1 and $0.5 \mathrm{mM}$ glutamate increased in a dose-dependent manner compared to those grown without glutamate. Similarly, a dose-dependent increase in dead cells was observed when the cells were treated with the medium made of ERW containing $0,0.1$ or $0.5 \mathrm{mM}$ glutamate. However, the number of dead cells grown in the medium with ERW containing 0.1 or $0.5 \mathrm{mM}$ glutamate was significantly reduced compared with those grown in the presence of the respective MQ-water controls (Figure $8(\mathrm{~b}),{ }^{* *} P<0.01$ ). The representative photographs are shown in Figure 8(a). The results indicate that ERW suppresses glutamate-induced cell death which correlated well with the suppression of $\mathrm{Ca}^{2+}$ influx.

\section{Discussion}

In the present study, ERW was confirmed to suppress $\mathrm{H}_{2} \mathrm{O}_{2}-$ induced cell death in N1E-115, PC12 and SFME cell lines. Further studies with N1E-115 cells demonstrated that the suppressive effect of ERW stemmed from its ROS scavenging ability. This finding is in accordance with the previous reports 


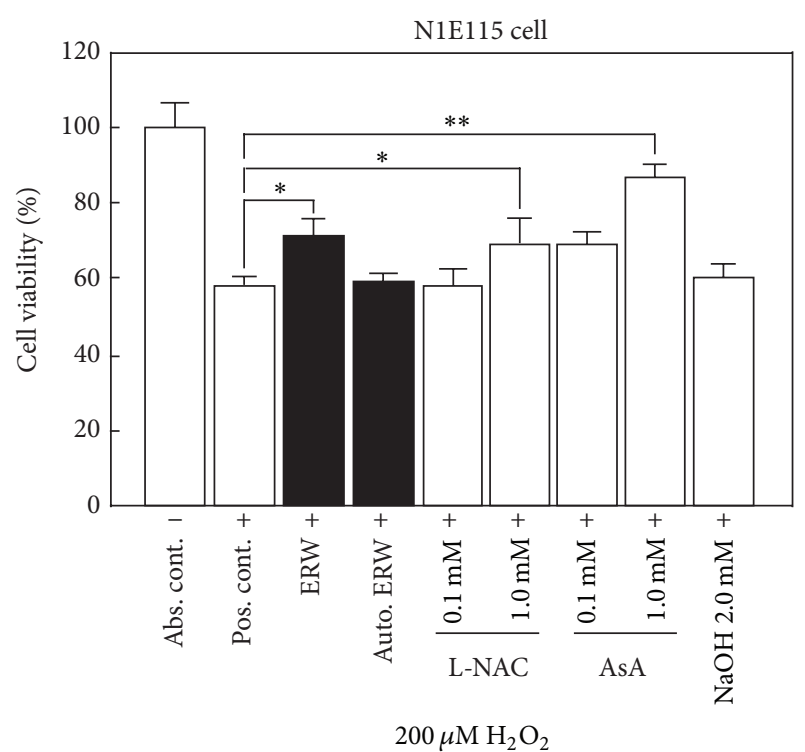

FIgURE 2: Protective effect of ERW against $\mathrm{H}_{2} \mathrm{O}_{2}$-induced cytotoxicity on N1E115 cells. N1E115 cells were preincubated with FBS/DMEM medium and were treated with serum-free medium made of MQwater, ERW, L-NAC $(0.1,1 \mathrm{mM})$, AsA $(0.1,1 \mathrm{mM})$, or $2 \mathrm{mM} \mathrm{NaOH}$ supplemented with or without $200 \mu \mathrm{M} \mathrm{H}_{2} \mathrm{O}_{2}$ for $24 \mathrm{~h}$. A WST8 kit was used to measure viable cell numbers at $450 \mathrm{~nm}$ using a microtiter plate reader. Data are expressed as mean \pm standard deviation (SD) for three independent experiments. ${ }^{*} P<0.05,{ }^{* *} P<$ 0.01. Abs. cont.: absolute control, Pos. cont.: positive control, Auto. ERW: autoclaved ERW.

obtained from pancreatic $\beta$-cell HIT-T15 cells $[15,19]$, human lung carcinoma A549 cells [41], HT1080 tumor cells [24], and diabetic $d b / d b$ mice [48].

The current study further revealed that ERW significantly suppresses cell death caused by glutamate- or SNP-induced stresses although it does not have direct NO scavenging activity. We pursued further experiments to unravel the mechanism underlying this phenomenon. Glutamate toxicity is mainly mediated by the glutamate receptor, NMDA, involving $\mathrm{Ca}^{2+}$ influx into cerebral cortex cells in the CNS [49]. Internalized $\mathrm{Ca}^{2+}$ and endogenous calmodulin together activate neuronal NO synthase for the production of NO. Importantly, neuroprotective NO is converted to neurodestructive $\mathrm{NO}$ radical $\left(\mathrm{NO}^{\circ}\right)$ depending on the redox condition in the neuronal cells [11]. Following $\mathrm{NO}^{\circ}$ production, it reacts with $\mathrm{O}_{2}{ }^{--}$to form $\mathrm{ONOO}^{-}$which decomposes to nitrite and highly reactive $\mathrm{HO}^{\circ}$, and the reactions proceed to generate stable nitrite/nitrate species. Such radicals liberated during the NO-cascade contribute to neurocytotoxicity [2, $10-12,50]$. Based on the information for $\mathrm{Ca}^{2+}$ influx induced by glutamate in cerebral cortex cells [49] and the NO-cascade as discussed above, we used MCCNP cells to assess whether ERW scavenges NO. Firstly, we found that ERW clearly suppressed $\mathrm{Ca}^{2+}$ influx in MCCNP cells and ERW suppressed extracellular $\mathrm{H}_{2} \mathrm{O}_{2}$ induced $\mathrm{Ca}^{2+}$ influx in $\mathrm{PC} 2$ cells (data not shown). Also, a previous study demonstrated that ERW prevents alloxan-induced elevation of intracellular $\mathrm{Ca}^{2+} \mathrm{lev}-$ els in HIT-T15 $\beta$-cells [19]. Moreover, exposure of rat mixed cortical neuron primary cells to $\mathrm{H}_{2} \mathrm{O}_{2}$ resulted in increases in intracellular $\mathrm{Ca}^{2+}$ levels which are suggested to be involved in $\mathrm{H}_{2} \mathrm{O}_{2}$-induced cell death [51]. Subsequently, $\mathrm{H}_{2} \mathrm{O}_{2}$-induced neuronal cell death was shown to be closely associated with NMDA mediated $\mathrm{Ca}^{2+}$ influx [52]. The present finding of the suppressive effect of ERW is intriguing because increased $\mathrm{Ca}^{2+}$ influx triggers calpain (a protease) activation leading to the cleavage of a neuron specific p 35 activator protein to $\mathrm{p} 25$ which binds to cyclin dependent kinase 5 (Cdk5) forming a hyperactive Cdk5/p25 complex. This deregulated Cdk5/p25 activity has been linked to be a causative factor of various neurodegenerative diseases [6]. Secondly, we used the trypan blue exclusion assay to evaluate the protective function of ERW on the cytotoxic effect induced by glutamate in MCCNP cells. ERW significantly suppressed glutamate induced cell death which is closely correlated with reduced $\mathrm{Ca}^{2+}$ influx. Finally, we performed experiments using SNP and PC12 cells in combination with the NO-specific DAR-4M AM probe to determine whether ERW scavenges NO directly. We utilized PC12 cells because this cell line has been described to be sensitive to NO [38]. To our surprise, ERW was not found to scavenge NO; nevertheless, the cell viability was significantly increased. In addition, in the presence of ERW, we did not observe the reduction of intracellular fluorescence intensities at SNP concentrations ranging from 50 to $500 \mu \mathrm{M}$ (data not shown). SNP has been used as a NO-donor $[30,49,50]$ and its metabolites have been suggested to be involved in redox cycling with oxygen to form $\mathrm{O}_{2}{ }^{\cdot-}$, which then produces $\mathrm{H}_{2} \mathrm{O}_{2}$, which in turn produces $\mathrm{HO}^{\circ}$ via the Fenton reaction [30]. Therefore, the presently observed suppressive effect of ERW on SNP induced PC12 cell death is mostly caused by its ROS scavenging ability and it is less likely that it can scavenge NO directly. The proposed points of action of ERW are shown in Figure 9.

The question remains as to what factors are responsible for the presently observed scavenging activity of ERW against ROS produced by glutamate, SNP, and $\mathrm{H}_{2} \mathrm{O}_{2}$. ERW has been shown to contain dissolved hydrogen (0.4-0.9 ppm) and Pt nanoparticles (nps) (0.1-2.5 ppb) as potential ROS scavenging substances [15-17]. Recently, we estimated the levels of dissolved hydrogen to be $0.76 \mathrm{ppm}$ in freshly prepared ERW with a half-life of approximately $100 \mathrm{~min}$ [24]. Direct involvement of hydrogen molecules as a ROS scavenger was reported using rat myotube L6 cells [53]. Also, hydrogen molecules were shown to enhance the expression of genes for antioxidant enzymes such as catalase, glutathione peroxidase, and heme oxygenase [53]. In another report, ERW was shown to restore the activities of superoxide dismutase, catalase, and glutathione peroxidase in mice, supporting the idea that ERW acts as an antioxidant and an ROS scavenger [25]. Similarly, an antioxidative role of ERW was reported in vitro and in vivo [54-56]. ERW was also reported to possess reducing activities because of the presence of dissolved molecular hydrogen [57, 58]. In vivo, $0.08 \mathrm{ppm}$ of hydrogen molecules were reported to be sufficient to exert antineurodegenerative effects in PD model mice [59]. Also, hydrogen molecules were shown to reduce ${ }^{\circ} \mathrm{OH}, \mathrm{ONOO}^{-}$and oxidative stress in the rat brain induced by focal ischemia and injury [60]. Recently, 


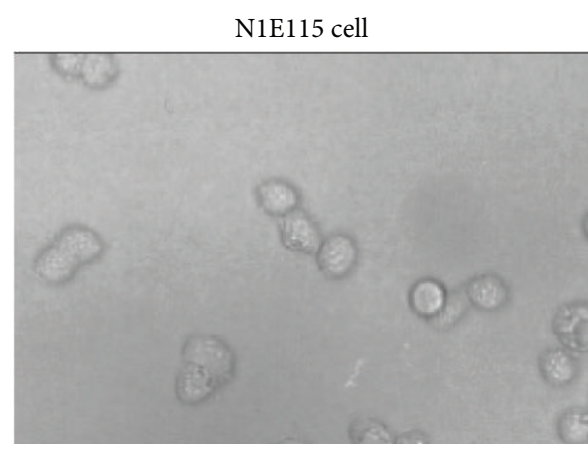

(a)

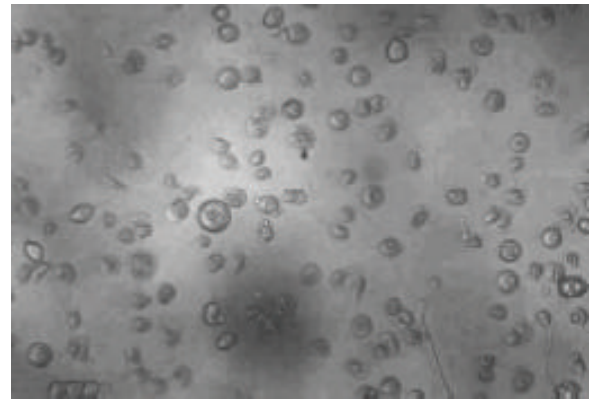

(c)

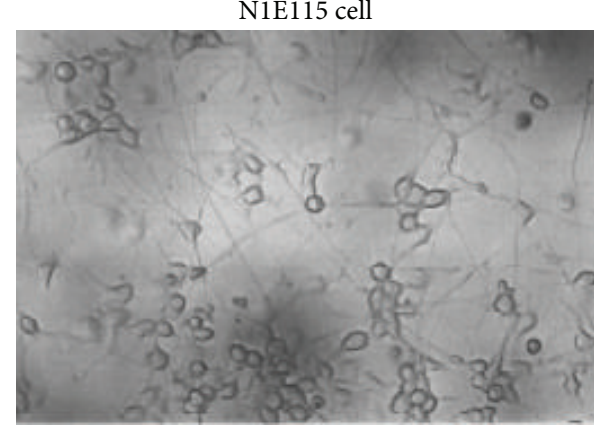

(b)

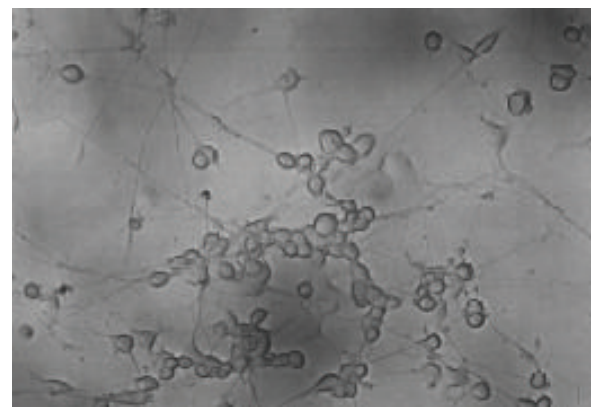

(d)

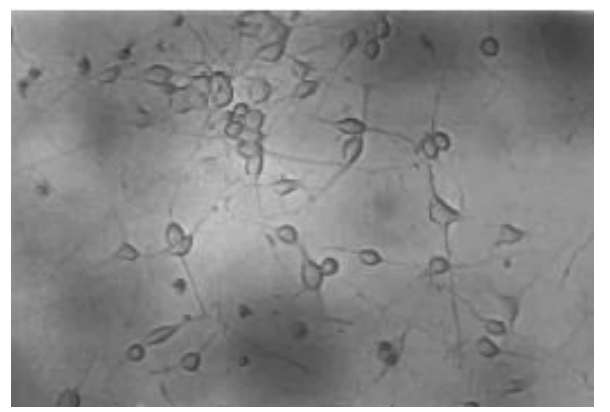

(e)

FIGURE 3: Protective effect of ERW on morphological changes against $\mathrm{H}_{2} \mathrm{O}_{2}$-induced oxidative stress on N1E115 cells. N1E115 cells were preincubated with FBS/DMEM medium and treated with serum-free medium made of MQ-water as the control (a), differentiated cells with DMSO (b), differentiated cells treated with $200 \mu \mathrm{M} \mathrm{H}_{2} \mathrm{O}_{2}$ (c), differentiated cells treated with ERW alone (d), and differentiated cells treated with ERW and $200 \mu \mathrm{M} \mathrm{H}_{2} \mathrm{O}_{2}$ (e) for $24 \mathrm{~h}$. Morphological changes were observed microscopically and photographed.

molecular hydrogen dissolved in ERW derived from tap water was reported to reduce LPS-induced neuroinflammation in mice [61]. Based on these studies, it is highly probable that hydrogen molecules in ERW can reach and deliver a neuroprotective effect in the brain.

Another potential factor which plays a role in the ROS scavenging activity of ERW is the Pt nps derived from the Pt-coated Ti electrodes during electrolysis. Comparative measurements using an inductively coupled plasma mass spectrometer (ICP-Ms) have shown that Pt nps and related compounds are detected only in the post-electrolyzed $2 \mathrm{mM}$ $\mathrm{NaOH}$ solution, that is, ERW, and not in the preelectrolyzed $\mathrm{NaOH}$ solution $[15,17]$. Furthermore, Pt nps in several ERW preparations were measured to range from 0.1 to $2.5 \mathrm{ppb}$ using ICP-MS [15-17, 21]. The variable amount of Pt nps in different ERW preparations was thought to result from the gradual erosion of Pt coated Ti-electrodes from repeated electrolysis [24]. It was also necessary to confirm if Pt nps can scavenge ROS. In this respect, it has been shown that synthetic Pt nps can directly scavenge $\mathrm{O}_{2}{ }^{\circ-}, \mathrm{HO}^{\circ}$, and $\mathrm{H}_{2} \mathrm{O}_{2}$ and are considered to be a multifaceted ROS scavenger [17, 62]. In agreement with our results, synthetic Pt nps have been reported to show ROS scavenging activity [63-65]. Moreover, it is noteworthy to mention that the liberated $\mathrm{Pt}$ nps generates active hydrogen from the hydrogen molecules simultaneously produced during electrolysis. In turn, the active hydrogen is adsorbed/absorbed to nearby Pt nps which may synergistically contribute to the scavenging effect of $\mathrm{Pt}$ nps $[62,66]$. We tested whether autoclaving will affect the antioxidative ability of ERW which resulted in the loss of the protective effect against $\mathrm{H}_{2} \mathrm{O}_{2}$-induced N1E-115 cell death. Similar results were reported in other cell lines and protecting 


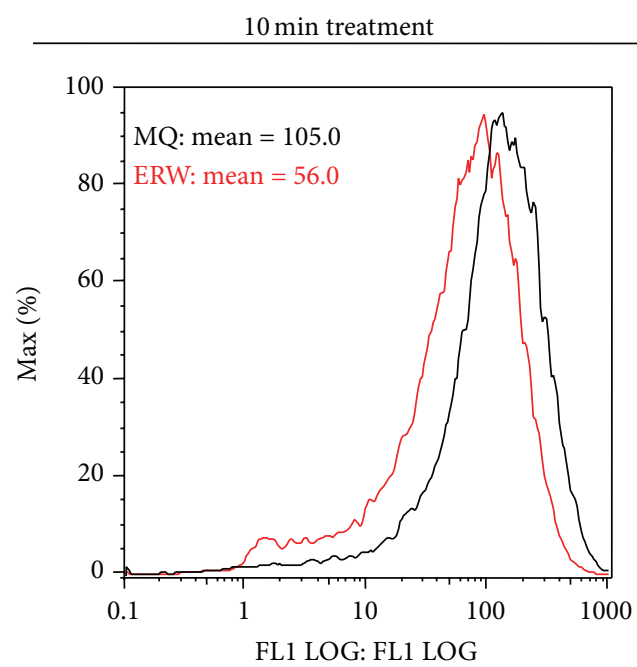

(a)

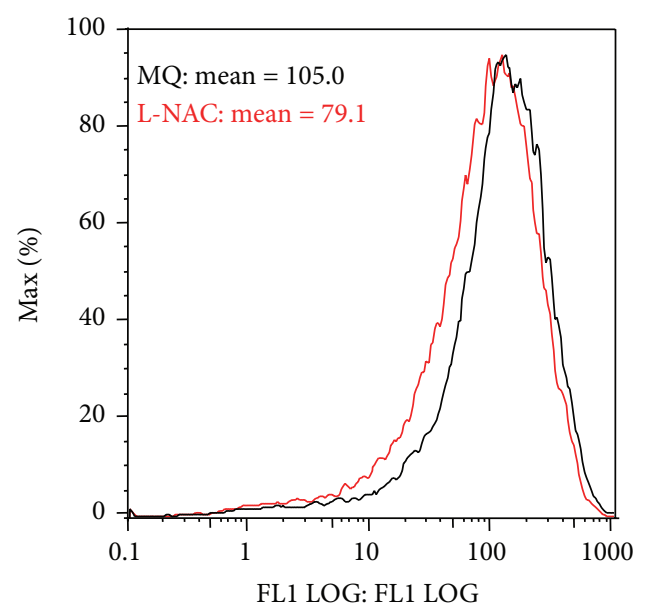

(c)

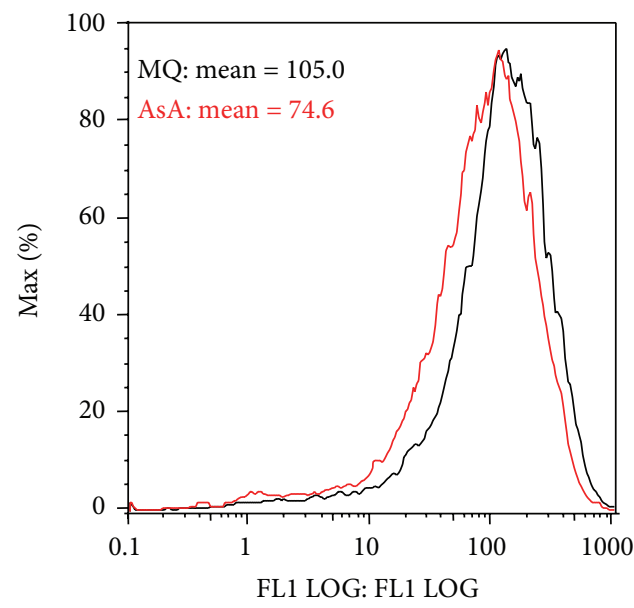

(e)

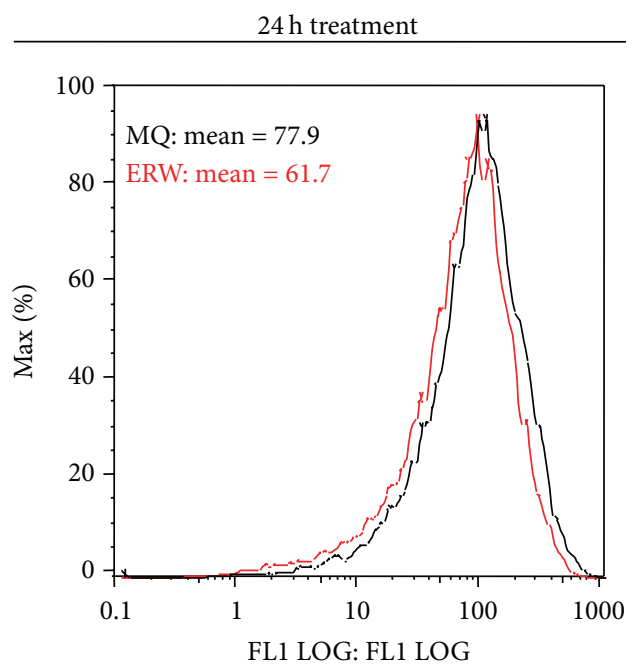

(b)

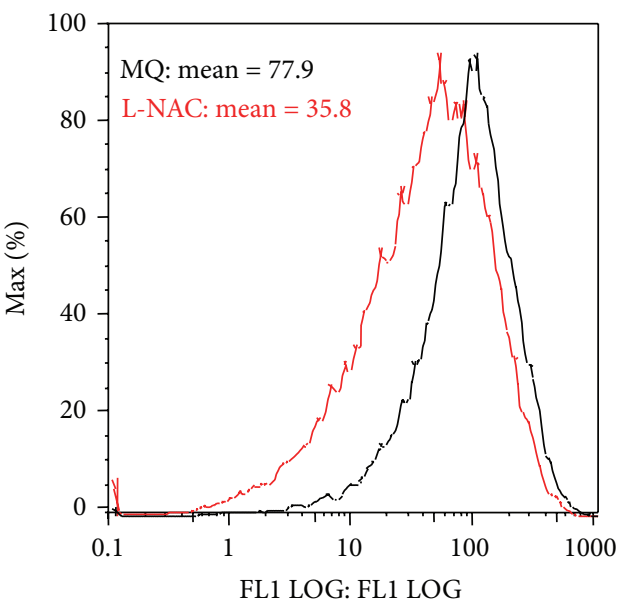

(d)

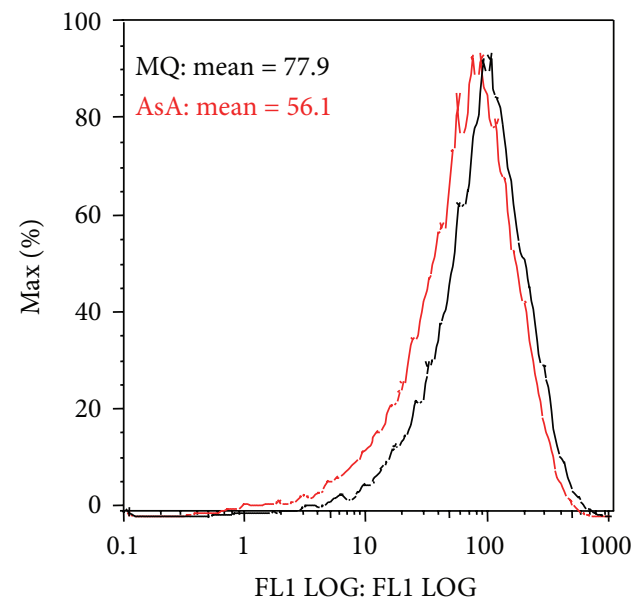

(f)

FIGURE 4: Flow cytometric analysis of the intracellular $\mathrm{H}_{2} \mathrm{O}_{2}$ scavenging ability of ERW on N1E115 cells. N1E-115 cells $\left(7.5 \times 10^{4}\right.$ cells $)$ were treated with ERW, L-NAC (1.0 mM), AsA (1.0 mM), or control MQ-water, and incubated for $10 \mathrm{~min}((\mathrm{a})$, (c), and (e)) or $24 \mathrm{~h}((\mathrm{~b}),(\mathrm{d})$, and (f)). After each treatment, cells were harvested and resuspended in $1 \mathrm{ml}$ PBS. Fluorescence intensities were measured immediately using an EPICS XL System II-JK flow cytometer with excitation and emission wavelengths of 495 and $525 \mathrm{~nm}$, respectively. Histograms were analyzed by using FlowJo software provided with the cytometer. 


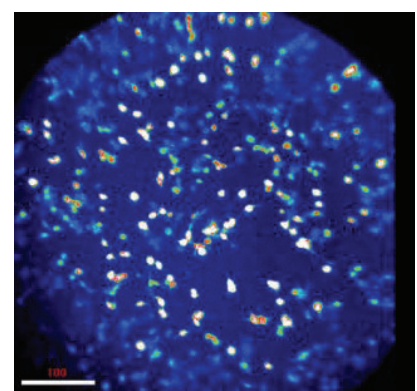

(a)

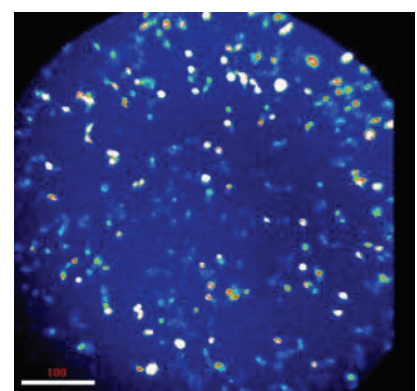

(b)

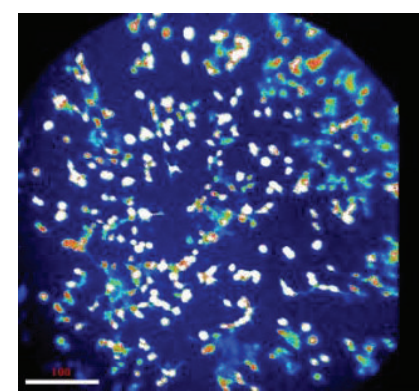

(c)

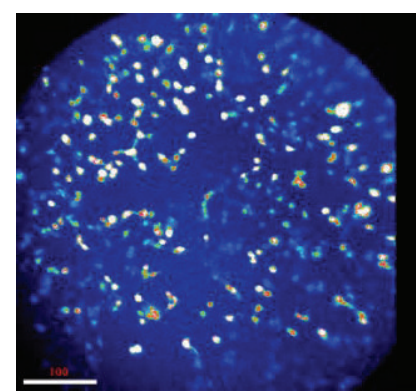

(d)

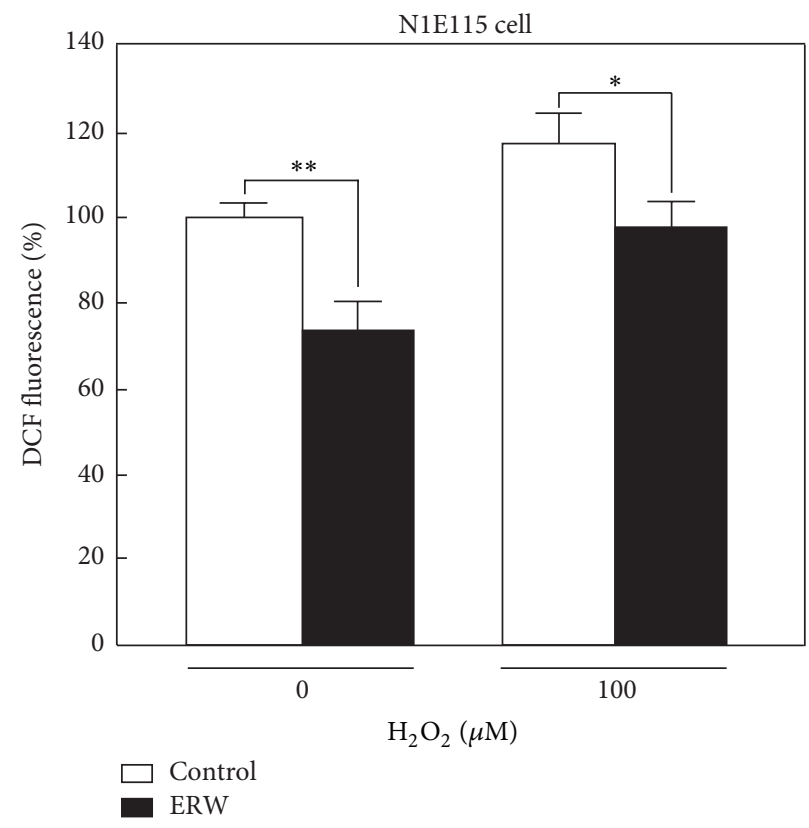

(e)

FIGURE 5: $\mathrm{H}_{2} \mathrm{O}_{2}$-induced ROS scavenging ability of ERW on N1E115 cells. Differentiated N1E115 cells were treated for 10 min with ERW with or without $200 \mu \mathrm{M} \mathrm{H}_{2} \mathrm{O}_{2}$ and intracellular $\mathrm{H}_{2} \mathrm{O}_{2}$ levels were detected with a DCFH-DA probe and measured using a confocal laser microscope. Representative photographs of three independent experiments are shown: (a) MQ control, (b) ERW, (c) $M Q+100 \mu M \mathrm{H}_{2} \mathrm{O}_{2}$, and (d) ERW $+100 \mu \mathrm{M} \mathrm{H}_{2} \mathrm{O}_{2}$. (e) Photographs were used to calculate intracellular fluorescence intensities reflecting $\mathrm{H}_{2} \mathrm{O}_{2}$ levels in the cells for each treatment. Data are expressed as mean \pm standard deviation (SD) for three independent experiments. ${ }^{*} P<0.05$ and ${ }^{* *} P<0.01$.

factors have been suggested to be heat unstable or volatile substances contained in the ERW [19]. It has been reported that synthetic Pt nps will agglomerate after autoclaving leading to inefficient cellular uptake and dissolved hydrogen molecules and active hydrogen adsorbed/absorbed in the Pt nps are thought to be forced out $[24,62]$. Therefore, autoclaving of ERW provides further support that it contains hydrogen molecules and Pt nps as active substances. For ERW to be useful for in vivo therapeutic applications, Pt nps must be able to reach brain cells. Following ingestion, Pt nps are required to survive several obstacles including intestinal cell wall penetration, blood flow, and the BBB before reaching the brain cells. Pt nps were shown to be taken up by cells via mainly pinocytosis $[62,67,68]$. Another critical obstacle which will limit the usefulness of Pt nps is their ability to cross the $\mathrm{BBB}$ as has been suggested for other antioxidants $[2,6]$. Several diseases including AD leads to reduced BBB integrity [69] suggesting that Pt nps has the opportunity to pass through the diseased $\mathrm{BBB}$ more easily than the healthy
$\mathrm{BBB}$ to gain access to the brain cells. A recent article identifies the hurdles associated with synthetic metal nps delivery to the brain [69]. Therefore, further in vivo studies are required to investigate Pt nps containing ERW as suggested for other metal nps [62, 69-71].

ROS have been regarded as toxic by-products of physiological metabolism and increased ROS generation and reduced mitochondrial membrane potential $(\Delta \Psi \mathrm{m})$ are closely associated with the oxidative stress in PC12 cells [72]. In the present study, ERW was found to protect 3 neuronal cell lines from direct oxidative damage induced by $\mathrm{H}_{2} \mathrm{O}_{2}$ implying that ERW protects mitochondria in neuronal cells. However, further investigation using N1E-115 cells treated with ERW $/ \mathrm{H}_{2} \mathrm{O}_{2}(200 \mu \mathrm{M})$ medium did not show significant restoration of $\Delta \Psi \mathrm{m}$ compared with the $\mathrm{MQ} / \mathrm{H}_{2} \mathrm{O}_{2}(200 \mu \mathrm{M})$ medium treated control (data not shown).

There are multiple pathways that induce cell apoptosis. Among these, ROS mediated pathways involving mitochondria are relevant to the results obtained in this study. 


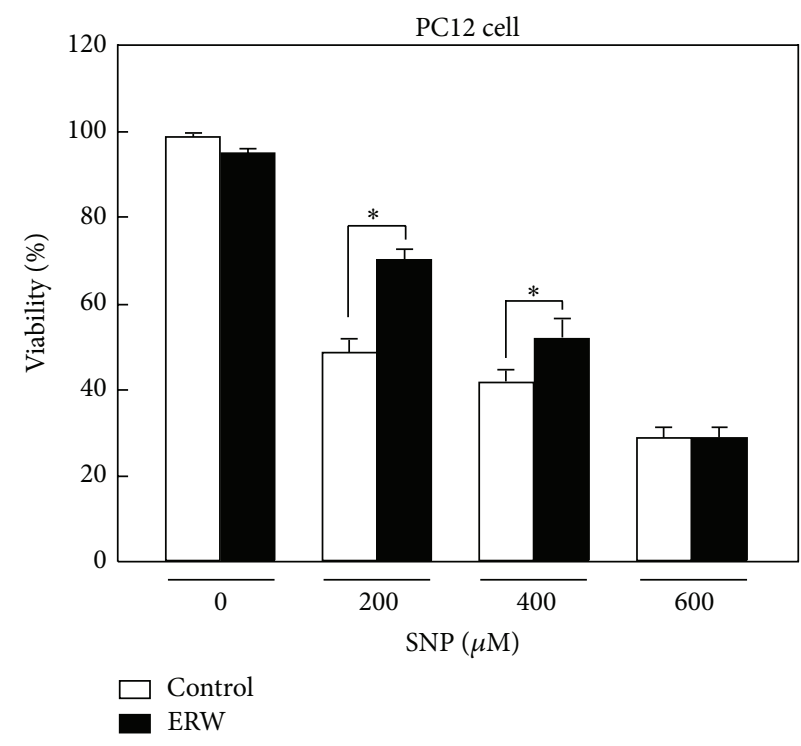

(a)

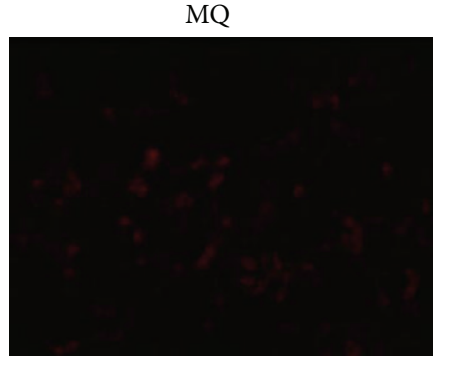

ERW

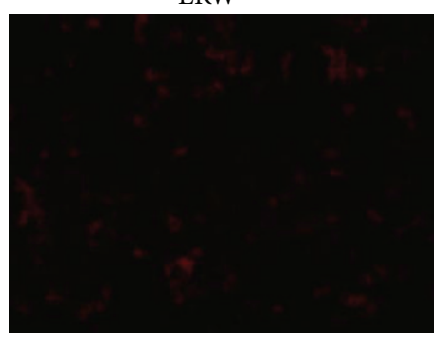

(b)

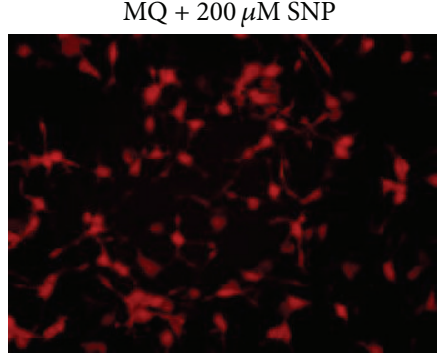

$\mathrm{ERW}+200 \mu \mathrm{M}$ SNP

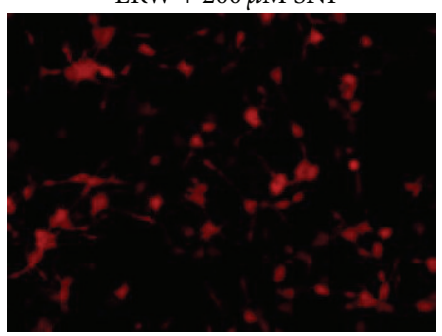

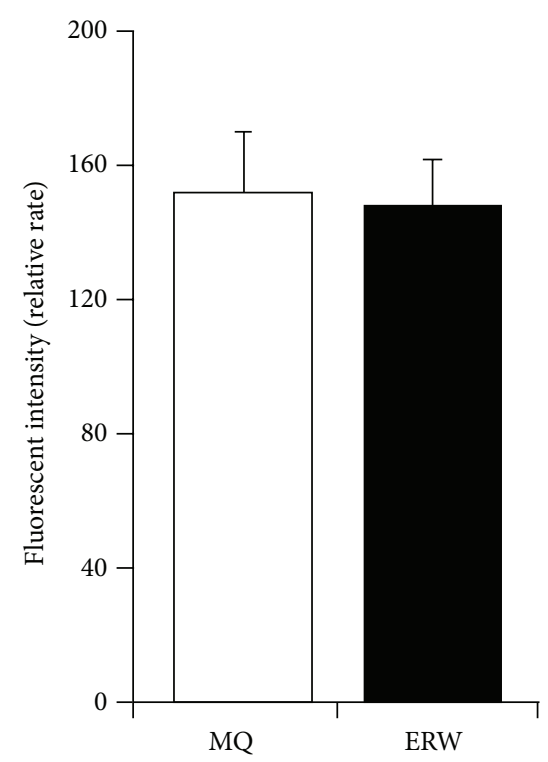

(c)

FIgURE 6: Suppressive effect of ERW on SNP-induced NO toxicity in PC12 cells. Cells were cultured for $24 \mathrm{~h}$ with the medium containing ERW or MQ-water each supplemented with 0, 200, 400, and $600 \mu \mathrm{M}$ SNP. (a) Cell viability was measured by a WST-8 kit. Data are expressed as mean \pm standard deviation (SD) for three independent experiments. ${ }^{*} P<0.05$. (b) ERW was assessed for its intracellular NO scavenging ability using the DAR-4M AM bioimaging probe. Representative photographs of NO dependent fluorescence levels incubated with MQ, ERW, and $200 \mu \mathrm{M}$ SNP added-MQ and ERW are shown. (c) Fluorescence intensities of 50 cells treated with MQ or ERW containing $200 \mu \mathrm{M}$ SNP were measured and Tukey's multiple comparison method was used to compare the effect of MQ and ERW.

ROS induced oxidative stress causes oxidative damage to vital cellular constituents, which eventually affect cell viability. ROS accumulation in cells mediates apoptosis by way of mitochondria-dependent and mitochondria-independent pathways. Elevated ROS levels in the cell will disturb the physiological balance maintained by the proapoptotic (for example Bax, Bak, Bok, Bid, and Bim) and antiapoptotic (for example $\mathrm{Bcl}-2, \mathrm{Bcl}-\mathrm{X}_{L}$, and $\mathrm{Bcl}-\mathrm{w}$ ) proteins, all of which belong to the $\mathrm{Bcl}-2$ family of proteins and generally act to induce apoptosis or survival of the cell. Apoptosis is induced when proapoptotic Bcl-2 family proteins (Bax, Bak, Bok, Bid, and Bim) are activated by death signals via death receptors (tissue necrosis factor receptor-1 (TNFR1), Fas, and TRAIL-R1). Tissue necrosis factor- $\alpha$ (TNF $\alpha)$ increases the ROS level, which in turn activates the apoptosis signal regulating the kinase 1-c-Jun $\mathrm{NH}_{2}$ terminal kinase (ASK1JNK) apoptotic pathway. Exogenously and endogenously derived ROS are considered the most effective activators of ASK1, which acts as a redox sensor because it contains the redox-sensitive regulatory protein thioredoxin (Trx) binding 


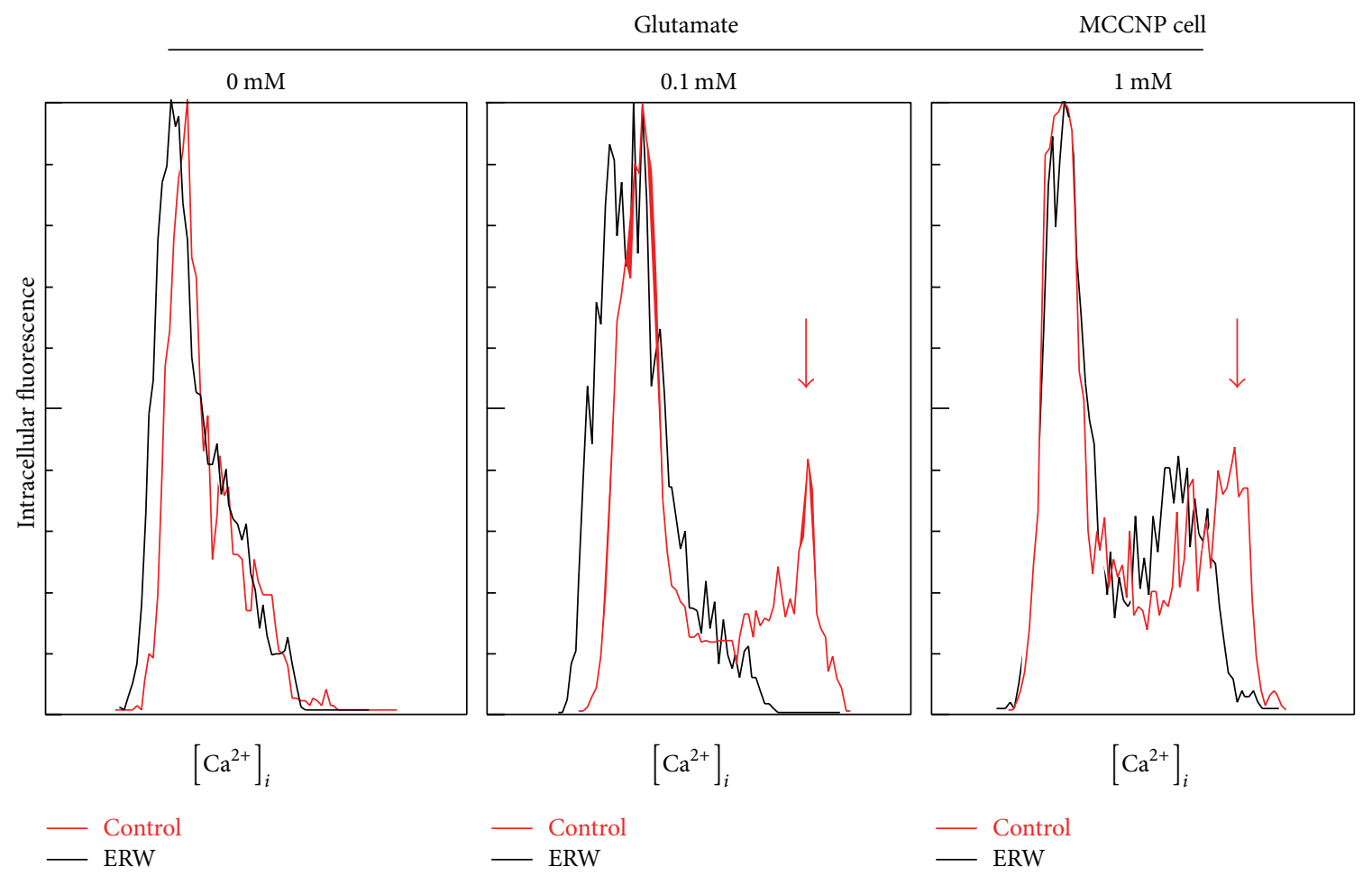

FIGURE 7: Suppressive effect of ERW on glutamate-induced $\mathrm{Ca}^{2+}$ influx in MCCNP cells. Intracellular Ca ${ }^{2+}$ was measured with Fluo-3 AM, a membrane-permeable calcium sensitive dye. Internalized Fluo-3 AM is hydrolyzed by intracellular esterases liberating Flou-3 which can react with intracellular free $\mathrm{Ca}^{2+}$ ions forming a fluorescent complex. After pretreatment with glutamate $(0,0.1$ or $1.0 \mathrm{mM})$ in the medium made with ERW or MQ-water for $15 \mathrm{~min}$, MCCNP cells were stained with Fluo-3 AM for 20 min and post-incubated with FBS/HBSS medium. A fluorescence microscope was used to detect intracellular fluorescence and the images were recorded by a digital camera. Digital images were converted to numerical data with the aid of the NIH image analysis program and then analyzed by Excel software. Representative histograms of triplicate independent experiments are shown.

domain. ROS inactivates Trx by oxidizing two cysteine residues in the redox center of Trx causing it to dissociate from ASK1. This allows ASK1 to be bound by the tumor necrosis factor receptor-associated factor 2 (TRAF2) and TRAF6 to form an active ASK1 signalosome that induces the autophosphorylation of ASK1. During the ASK1 activation process under oxidative stress, the 14-3-3 proteins binding site at Ser-966 of ASK1 is dephosphorylated resulting in the dissociation of 14-3-3 proteins which are facilitated by the ROS activated mammalian sterile 20 (Mst) family member SOK-1. The ROS activated ASK1 eventually activates the JNK cascade and sustained JNK activity leads to apoptosis. Thus, oxidative stress activates ASK1 which phosphorylates the MAPKK-JNK and -p38 pathways. Activated JNK directly phosphorylates p53 rendering it to translocate to the nucleus, allowing up-regulation of proapoptotic genes such as the p53 upregulated modulator of apoptosis (PUMA) and BCL2associated $\mathrm{X}$ protein (Bax). Alternatively, the phosphorylated JNK relocates to the nucleus and phosphorylates $\mathrm{c}$-jun to form activator protein 1 (AP-1) resulting in the up-regulation of proapoptotic genes such as TNF $\alpha$, Fas-L, and Bak. Moreover, activated JNK moves to the nearby mitochondria and binds to the complexes of proapoptotic Bax and tBid produced from proapoptotic Bid by active caspase- 8 and then $\mathrm{tBid}$ with $\mathrm{Bax} / \mathrm{Bax}$ and $\mathrm{Bak} / \mathrm{Bak}$ oligomers initiate pore formation in the outer mitochondrial membrane (OMM) causing the release of cytochrome c. Additionally, other factors including AIF, EndoG, and CAD, which relocate to the nucleus for DNA fragmentation, and the proapoptotic protein second mitochondrial activator of the caspase/direct inhibitor of the apoptosis protein binding protein with low pI (Smac/DIABLO) and mammalian serine protease (HtrA2/Omi) induce apoptosis via indirect activation of caspase- 8 apoptotic pathways. Released cytochrome $\mathrm{c}$ forms an apoptosome with Apaf-1 and procaspase- 9 resulting in the formation of active caspase-9, which activates the executioner caspase-3. Separately, caspase- 3 gets activated by the active caspase-8. Activated caspase- 3 executes cell destruction by cleaving various vital constituents in the cells. Caspases are constitutive residents of the cytosol as inactive zymogen monomers and are activated for example by endogenously and exogenously generated $\mathrm{H}_{2} \mathrm{O}_{2}$ through oxidation of the cysteine catalytic sites. Exposure to $\mathrm{H}_{2} \mathrm{O}_{2}$ decreases the mitochondrial transmembrane potential $(\Delta \Psi \mathrm{m})$ and oxidizes the mitochondrial permeability proteins comprising voltage dependent anion channel (VDAC), adenine nucleotide translocase (ANT), and cyclophilin $\mathrm{D}(\mathrm{CyD})$ leading to mitochondrial $\mathrm{Ca}^{2+}$ influx. Thus, reduced $\Delta \Psi \mathrm{m}$, elevated $\mathrm{Ca}^{2+}$ levels, and oxidative stress induce enlargement of the mitochondrial permeability transition pore (MPTP) located at 

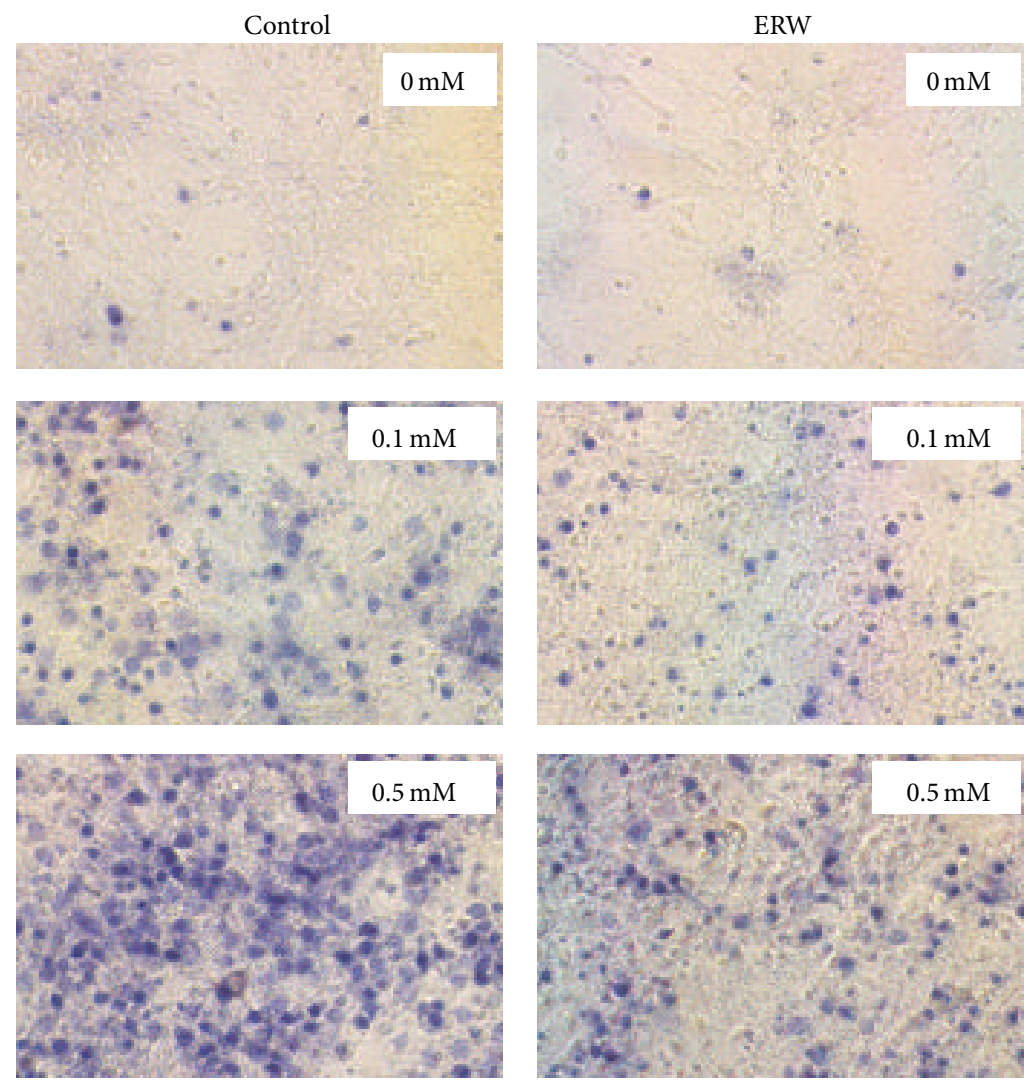

(a)

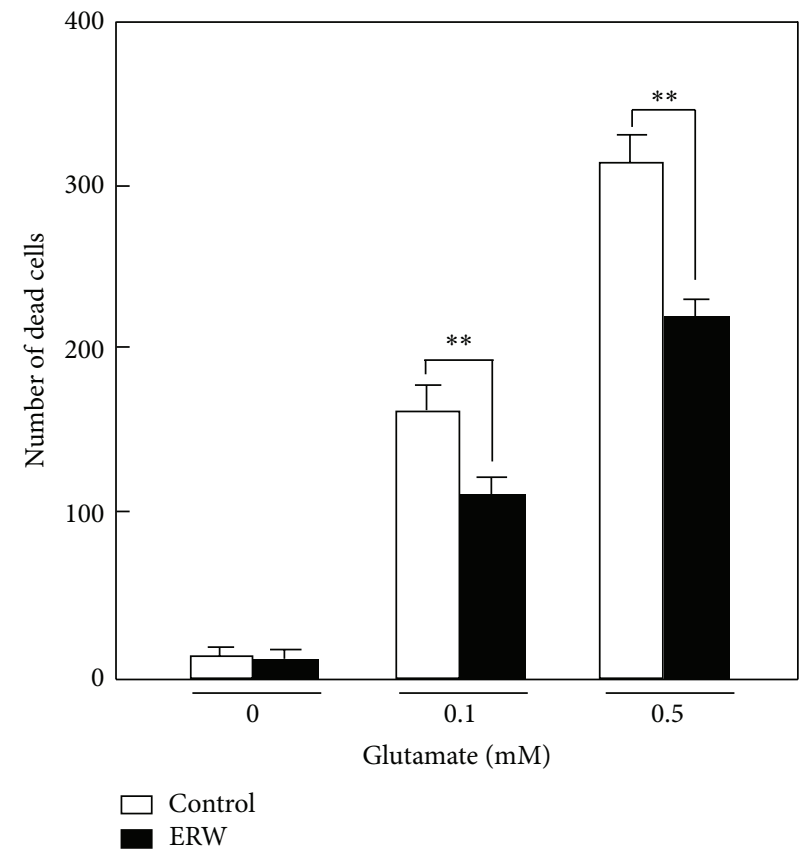

(b)

FIGURE 8: Protective effect of ERW against glutamate toxicity on MCCNP cells. After MCCNP cells were treated with $0,0.1$, and $0.5 \mathrm{mM}$ glutamate in the medium made of ERW or MQ-water for $24 \mathrm{~h}$, nonviable cells were stained with trypan blue dye. Nonviable cells stained blue were counted for 8 randomly selected fields as one set and 4 sets for each treatment were counted under the microscope. Representative photographs are presented in (a) from which stained cell counts were statistically analyzed as shown in (b). Data are expressed as mean \pm standard deviation (SD) for four independent experiments. ${ }^{* *} P<0.01$. 


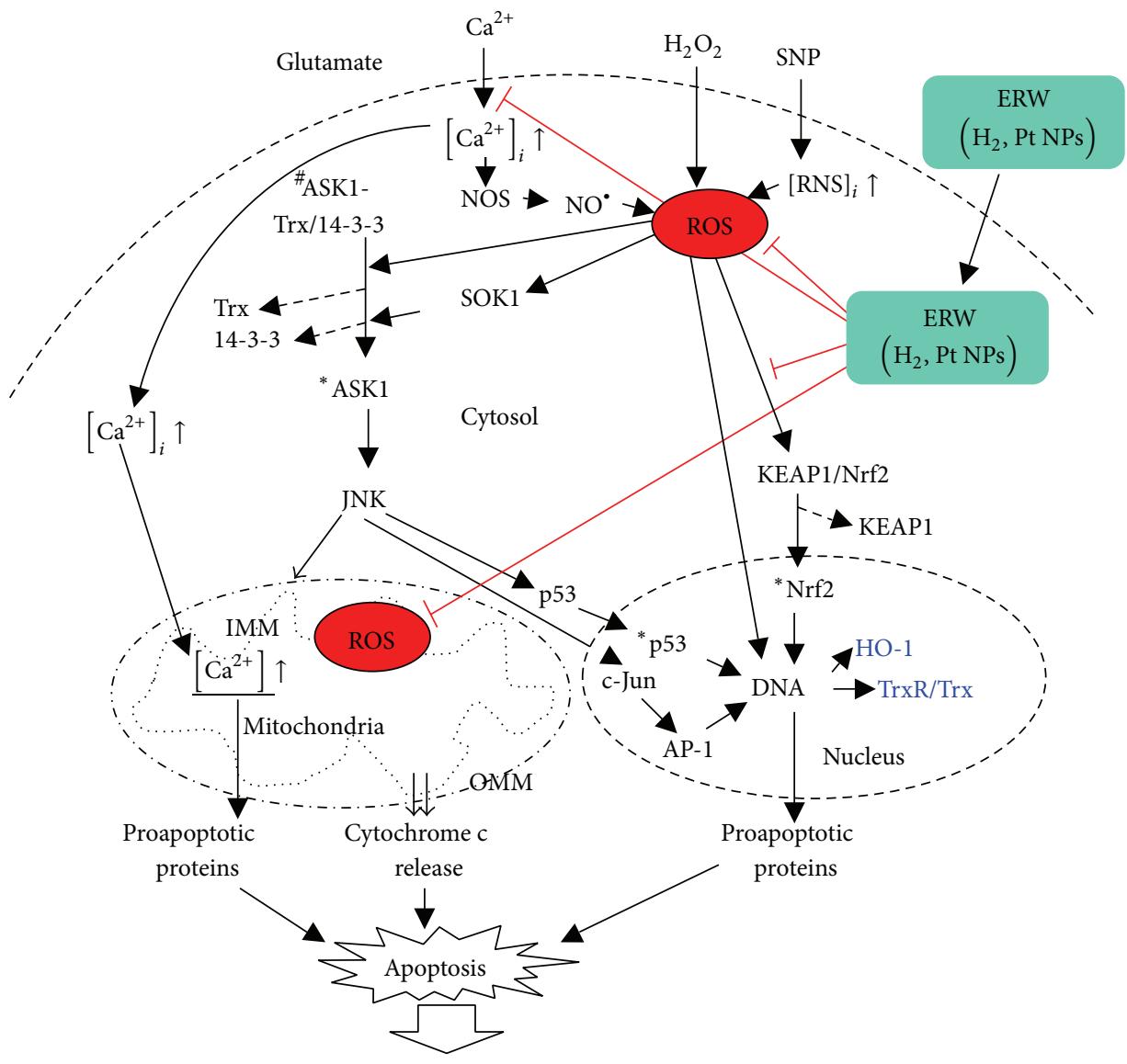

$\mathrm{AD}, \mathrm{PD}, \mathrm{HD}, \mathrm{ALS}, \mathrm{CVD}$

FIGURE 9: Schematic representation of possible points of action for the suppressive effects of ERW against stressors. Glutamate induces Ca ${ }^{2+}$ influx leading to increased neuronal cell death. SNP increases neuronal cell death by inducing NO. A reduction of neuronal cells eventually leads to NDs. ERW suppresses $\mathrm{Ca}^{2+}$ influx and scavenges ROS, thereby protecting neuronal cell death. Arrows indicate a single step or multiple intermediary steps responsible for upregulating the proapoptotic genes triggered by ROS, RNS, and $\mathrm{Ca}^{2+}$. HO- 1 and TrxR/Trx, which are controlled by vitagenes, act as homeostasis keepers within a tolerable stress zone and are included in blue font. ${ }^{\#}$ indicates inactive state. ${ }^{*}$ indicates activated state. $(\uparrow)$ is increased intracellular $\mathrm{Ca}^{2+}$ and RNS levels. Symbol $(\vdash)$ with red color represents prospective points of action of ERW.

the inner-outer membrane contact site to release cytochrome c. Elevated ROS will damage nuclear DNA directly and, in particular, $\mathrm{H}_{2} \mathrm{O}_{2}$ stimulates the nuclear accumulation of Forkhead box O3 (FOXO3) transcription factor, which transactivates the Bcl-2 interacting mediator of cell death (Bim) and other genes. Activated Bim is then translocated to the mitochondria causing a ROS burst via respiratory chain uncoupling. At the intermitochondrial membrane (IMM), this and other events of proapoptotic protein activation induce OMM perforation in a Bax/Bak dependent-manner [73-77]. Therefore, elevated ROS affects multiple sites that drive the cells toward apoptosis. The present results can be used to elucidate the possible ERW action sites contributing to the increased cell viability. ERW contains hydrogen molecules and Pt Nps as potential functional components as described above. Dissolved hydrogen molecules diffused in cells have been shown to reduce intracellular hydroxyl radicals $[78,79]$. Pt Nps have been shown to be taken up by pinocytosis, diffusion, and other processes and act as novel ROS scavengers in vitro and in vivo [80, 81]. Internalized functional components are capable of scavenging ROS produced by cytotoxic stimuli such as $\mathrm{H}_{2} \mathrm{O}_{2}$, SNP, and glutamate used in this study. Based on the pathways mentioned above, ERW could scavenge ROS to prevent thioredoxin (Trx) inactivation and inhibit SOK1 activation, thereby preventing active ASK1 signalosome formation. An inactive ASK1 signalosome becomes incapable of forwarding the ASK1-JNK pathway and prevents subsequent apoptosis prone signals including cytochrome c rerelease, p53 activation, and AP-1 formation. $\mathrm{H}_{2} \mathrm{O}_{2}$ scavenging prevents intracellular $\mathrm{Ca}^{2+}$ accumulation. Moreover, scavenging $\mathrm{H}_{2} \mathrm{O}_{2}$ is likely to prevent the nuclear accumulation of FOXO3 that subsequently induces mitochondrial ROS burst. The present results of reduced ROS and $\left[\mathrm{Ca}^{2+}\right]_{i}$ levels cooperatively contribute to improve the mitochondrial integrity leading to the increased cell viability. At present, the mechanism by which ERW functioned to 
reduce the $\left[\mathrm{Ca}^{2+}\right]_{i}$ level is not clear and further studies are required. The proposed points of action of ERW on cellular stressors are shown in Figure 9.

In the present study, the cell viability was found to be significantly improved because of the ROS scavenging ability of ERW. It is known that excessively produced ROS lead to oxidative stress and neurodegenerative diseases. The present study simulated excess ROS/RNS levels by applying $\mathrm{H}_{2} \mathrm{O}_{2}$, glutamate, and SNP to the cells. Recent reports emphasize that cells that possess a group of genes termed vitagenes have a better ability to maintain cellular homeostasis under various stress conditions. Based on the hormetic concept, low doses of oxidative stresses may induce cellular defense pathways to mediate a hormetic adaptive response conferred by the expression of vitagenes coding for stress resistance proteins that maintain cellular homeostasis. Vitagenes include the genes coding for the heat shock proteins (HSP) such as Hsp32 (also called Heme oxygenase 1, HO-1) and Hsp70, sirtuins, and the thioredoxin/thioredoxin reductase systems. Under oxidative conditions, the Hsps protects brain cells by degrading the prooxidant heme to free iron, carbon monoxide, and biliverdin, which in turn is reduced by biliverdin reductase to bilirubin, which possess endogenous NO and RNS scavenging abilities. Conversely, excess bilirubin production becomes neurotoxic by way of cell membrane disruption, mitochondrial transmembrane potential $(\Delta \Psi \mathrm{m})$ reduction, and apoptotic pathway activation. Thus, HO-1 repression is important for cell survival as excess bilirubin is cytotoxic. The heme oxygenases function as oxidative stress sensors and modulators of redox homeostasis. SIRT1 (silent information regulator 2 (Sir2) protein 1) is a sirtuin possessing histone deacylase activity and it plays a role in the hormetic response of cells to oxidative stressors. Sirtuins in the presence of $\mathrm{NAD}^{+}$as a cofactor deacylate transcription factors such as Nrf2, p53, FOXO (Forkhead box O), and nuclear factor- $\kappa \mathrm{B}$ (NF- $\kappa \mathrm{B}) \cdot \mathrm{H}_{2} \mathrm{O}_{2}$ is known to upregulate SIRT2 expression and it binds to FOXO3a enhancing its binding to target genes such as MnSOD. Thus, increased SIRT1 and SIRT2 expression contributes to ROS reduction. Also, the FOXO subfamily of transcription factors transactivates the Bcl-2 interacting mediator of cell death (Bim) and other genes. Another vitagene system is the thioredoxin/thioredoxin reductase (Trx and Trx reductase) system. Trx exists as a cytoplasmic protein (Trx-1) and a mitochondrial (Trx-2) protein essential for cell survival. It regulates cellular redox balance by reversible oxidation of the two cysteine residues in the redox center of Trx. Trx acts as an antioxidant or ROS scavenger as it eliminates singlet oxygen $\left({ }^{1} \mathrm{O}_{2}\right)$, hydroxyl radical $\left(\mathrm{OH}^{*}\right)$, and hydrogen peroxide $\left(\mathrm{H}_{2} \mathrm{O}_{2}\right) \cdot \mathrm{H}_{2} \mathrm{O}_{2}$ stimulates Trx-1 expression by the transcription factor Nrf2 and numerous stimuli including $\mathrm{H}_{2} \mathrm{O}_{2}$, hypoxia, and UV irradiation will direct translocation of Trx to the nucleus where it regulates the activities of critical transcription factors such as AP-1 members, NF-kB, p53, and Jun, which all are related to apoptosis pathways [82-87]. Vitagenes could function in preserving cellular homeostasis during stressful circumstances within a tolerable dose range, the hormetic zone. However, beyond this hormetic zone, higher degrees of oxidative stresses are thought to disrupt cellular redox homeostasis. In the present study, we monitored cell viabilities affected by various concentrations of $\mathrm{H}_{2} \mathrm{O}_{2}$, glutamate, and SNP. The results demonstrated that the cell viabilities were increased or recovered significantly except samples treated with the lowest and the highest concentrations of the stressors. From the results, it is possible that the reduced ROS induced by the presence of ERW in the cell could have modulated the oxidative states such that they fell again within the range of the hormetic zone, thereby allowing vitagenes to exert their activities.

\section{Conclusion}

ERW was found to protect N1E-115, PC12, SFME, and MCCNP cells from oxidative stresses caused by $\mathrm{H}_{2} \mathrm{O}_{2}$, glutamate, and SNP treatments. This neuronal cell protection stemmed from the ROS specific scavenging ability of dissolved hydrogen and Pt nps in the ERW. The present communication provides encouraging data for the therapeutic applicability of ERW against NDs.

\section{Abbreviations}

$\begin{array}{ll}\text { AD: } & \text { Alzheimer's disease } \\ \text { ALS: } & \text { Amyotrophic lateral sclerosis } \\ \text { Ara-C: } & \text { Cytosine } \beta \text {-D-arabinofuranoside } \\ & \text { hydrochloride } \\ \text { AsA: } & \text { Ascorbic acid } \\ \text { BBB: } & \text { Blood brain barrier } \\ \text { CDL: } & \text { Chemically defined lipid } \\ \text { CNS: } & \text { Central nervous system } \\ \text { DAR-4M AM: } & \text { Diaminorhodamine-4M acetoxymethyl } \\ & \text { ester } \\ \text { DCFH-DA: } & 2^{\prime}, 7^{\prime} \text {-Dichlorofluorescin diacetate } \\ \text { DMSO: } & \text { Dimethyl sulfoxide } \\ \text { ERW: } & \text { Electrolyzed reduced water } \\ \text { HD: } & \text { Huntington's disease } \\ \text { OH: } & \text { Hydroxyl radical } \\ \text { HEPES: } & \text { 4-[2-Hydroxyethyl]-1- } \\ & \text { piperazineethane-sulfonic acid } \\ \text { L-NAC: } & \text { N-Acetyl-L-cysteine } \\ \text { NO: } & \text { Nitric oxide } \\ \text { mEGF: } & \text { Mouse epidermal growth factor } \\ \text { NOS: } & \text { Nitric oxide synthase } \\ \text { NO: } & \text { Nitric oxide radical } \\ \text { NMDA: } & \text { N-Methyl-D-aspartate } \\ \text { ONOO' }: & \text { Peroxynitrite } \\ \text { PD: } & \text { Parkinson's disease } \\ \text { Pt: } & \text { Platinum } \\ \text { RNS: } & \text { Reactive nitrogen species } \\ \text { ROS: } & \text { Reactive oxygen species } \\ \text { SNP: } & \text { Sodium nitroprusside } \\ \text { O2-- } & \text { Superoxide radical. } \\ & \end{array}$

\section{Conflict of Interests}

The authors declare that there is no potential conflict of interests. 


\section{References}

[1] P. H. Reddy, "Mitochondrial medicine for aging and neurodegenerative diseases," NeuroMolecular Medicine, vol. 10, no. 4, pp. 291-315, 2008.

[2] A. Melo, L. Monteiro, R. M. F. Lima, D. M. de Oliveira, M. D. de Cerqueira, and R. S. El-Bachá, "Oxidative stress in neurodegenerative diseases: mechanisms and therapeutic perspectives," Oxidative Medicine and Cellular Longevity, vol. 2011, Article ID 467180, 14 pages, 2011.

[3] S. Gandhi and A. Y. Abramov, "Mechanism of oxidative stress in neurodegeneration," Oxidative Medicine and Cellular Longevity, vol. 2012, Article ID 428010, 11 pages, 2012.

[4] M. T. Lin and M. F. Beal, "Mitochondrial dysfunction and oxidative stress in neurodegenerative diseases," Nature, vol. 443, no. 7113, pp. 787-795, 2006.

[5] M. Karbowski and A. Neutzner, "Neurodegeneration as a consequence of failed mitochondrial maintenance," Acta Neuropathologica, vol. 123, no. 2, pp. 157-171, 2012.

[6] V. Shukla, S. K. Mishra, and H. C. Pant, "Oxidative stress in neurodegeneration," Advances in Pharmacological Sciences, vol. 2011, Article ID 572634, 13 pages, 2011.

[7] D. G. Smith, R. Cappai, and K. J. Barnham, "The redox chemistry of the Alzheimer's disease amyloid $\beta$ peptide," Biochimica et Biophysica Acta, vol. 1768, no. 8, pp. 1976-1990, 2007.

[8] A. Nunomura, K. Honda, A. Takeda et al., "Oxidative damage to RNA in neurodegenerative diseases," Journal of Biomedicine and Biotechnology, vol. 2006, Article ID 82323, 6 pages, 2006.

[9] M. Tanaka, P. B. Chock, and E. R. Stadtman, "Oxidized messenger RNA induces translation errors," Proceedings of the National Academy of Sciences of the United States of America, vol. 104, no. 1, pp. 66-71, 2007.

[10] Z. Radak, Z. Zhao, S. Goto, and E. Koltai, "Age-associated neurodegeneration and oxidative damage to lipids, proteins and DNA," Molecular Aspects of Medicine, vol. 32, no. 4-6, pp. 305315, 2011.

[11] S. A. Lipton, Y.-B. Choi, Z.-H. Pan et al., "A redox-based mechanism for the neuroprotective and neurodestructive effects of nitric oxide and related nitroso-compounds," Nature, vol. 364, no. 6438, pp. 626-632, 1993.

[12] T. Kume, H. Katsuki, and A. Akaike, "Endogenous factors regulating neuronal death induced by radical stress," Biological and Pharmaceutical Bulletin, vol. 27, no. 7, pp. 964-967, 2004.

[13] N. Ghosh, R. Ghosh, and S. C. Mandal, "Antioxidant protection: a promising therapeutic intervention in neurodegenerative disease," Free Radical Research, vol. 45, no. 8, pp. 888-905, 2011.

[14] B. Halliwell, "Free radicals and antioxidants: updating a personal view," Nutrition Reviews, vol. 70, no. 5, pp. 257-265, 2012.

[15] Y. Li, T. Hamasaki, N. Nakamichi et al., "Suppressive effects of electrolyzed reduced water on alloxan-induced apoptosis and type 1 diabetes mellitus," Cytotechnology, vol. 63, no. 2, pp. 119131, 2011.

[16] H. Yan, H. Tian, T. Kinjo et al., "Extension of the lifespan of caenorhabditis elegans by the use of electrolyzed reduced water," Bioscience, Biotechnology and Biochemistry, vol. 74, no. 10, pp. 2011-2015, 2010.

[17] S. Shirahata, T. Hamasaki, and K. Teruya, "Advanced research on the health benefit of reduced water," Trends in Food Science \& Technology, vol. 23, no. 2, pp. 124-131, 2012.

[18] S. Shirahata, S. Kabayama, M. Nakano et al., "Electrolyzedreduced water scavenges active oxygen species and protects
DNA from oxidative damage," Biochemical and Biophysical Research Communications, vol. 234, no. 1, pp. 269-274, 1997.

[19] Y. Li, T. Nishimura, K. Teruya et al., "Protective mechanism of reduced water against alloxan-induced pancreatic $\beta$-cell damage: scavenging effect against reactive oxygen species," Cytotechnology, vol. 40, no. 1-3, pp. 139-149, 2002.

[20] C.-F. Tsai, Y.-W. Hsu, W.-K. Chen et al., "Hepatoprotective effect of electrolyzed reduced water against carbon tetrachlorideinduced liver damage in mice," Food and Chemical Toxicology, vol. 47, no. 8, pp. 2031-2036, 2009.

[21] H. Yan, T. Kinjo, H. Tian et al., "Mechanism of the lifespan extension of Caenorhabditis elegans by electrolyzed reduced water-participation of PT nanoparticles," Bioscience, Biotechnology and Biochemistry, vol. 75, no. 7, pp. 1295-1299, 2011.

[22] K.-C. Huang, C.-C. Yang, K.-T. Lee, and C.-T. Chien, "Reduced hemodialysis-induced oxidative stress in end-stage renal disease patients by electrolyzed reduced water," Kidney International, vol. 64, no. 2, pp. 704-714, 2003.

[23] K.-C. Huang, S.-P. Hsu, C.-C. Yang et al., "Electrolysed-reduced water dialysate improves T-cell damage in end-stage renal disease patients with chronic haemodialysis," Nephrology Dialysis Transplantation, vol. 25, no. 8, pp. 2730-2737, 2010.

[24] T. Kinjo, J. Ye, H. Yan et al., "Suppressive effects of electrochemically reduced water on matrix metalloproteinase-2 activities and in vitro invasion of human fibrosarcoma HT1080 cells," Cytotechnology, vol. 64, no. 3, pp. 357-371, 2012.

[25] C.-F. Tsai, Y.-W. Hsu, W.-K. Chen, Y.-C. Ho, and F.-J. Lu, "Enhanced induction of mitochondrial damage and apoptosis in human leukemia HL-60 cells due to electrolyzed-reduced water and glutathione," Bioscience, Biotechnology and Biochemistry, vol. 73, no. 2, pp. 280-287, 2009.

[26] H. Yan, T. Kashiwaki, T. Hamasaki et al., "The neuroprotective effects of electrolyzed reduced water and its model water containing molecular hydrogen and Pt nanoparticles," $B M C$ Proceedings, vol. 5, article P69, supplement 8, 2011.

[27] G. J. Harry, M. Billingsley, A. Bruinink et al., "In vitro techniques for the assessment of neurotoxicity," Environmental Health Perspectives, vol. 106, supplement 1, pp. 131-158, 1998.

[28] T. Amano, E. Richelson, and M. Nirenberg, "Neurotransmitter synthesis by neuroblastoma clones," Proceedings of the National Academy of Sciences of the United States of America, vol. 69, no. 1, pp. 258-263, 1972.

[29] H. Li, H.-C. Chen, and F. L. Huang, "Identification of a rapidly dephosphorylating $95-\mathrm{kDa}$ protein as elongation factor 2 during 8-Br-cAMP treatment of N1E115 neuroblastoma cells," Biochemical and Biophysical Research Communications, vol. 217, no. 1, pp. 131-137, 1995.

[30] M. Yamada, K. Momose, E. Richelson, and M. Yamada, "Sodium nitroprusside-induced apoptotic cellular death via production of hydrogen peroxide in murine neuroblastoma N1E-115 cells," Journal of Pharmacological and Toxicological Methods, vol. 35, no. 1, pp. 11-17, 1996.

[31] J.-E. Oh, K. R. Karlmark, J.-H. Shin et al., "Differentiation of neuroblastoma cell line N1E-115 involves several signaling cascades," Neurochemical Research, vol. 30, no. 3, pp. 333-348, 2005.

[32] N. Matuszak, L. Hamtiaux, B. Baldeyroux et al., "Dual inhibition of MAGL and type II topoisomerase by $N$-phenylmaleimides as a potential strategy to reduce neuroblastoma cell growth," European Journal of Pharmaceutical Sciences, vol. 45, no. 3, pp. 263-271, 2012. 
[33] J.-E. Oh, A. Freilinger, E. Gelpi, A. Pollak, M. Hengstschläger, and G. Lubec, "Proteins involved in neuronal differentiation of neuroblastoma cell line N1E-115," Electrophoresis, vol. 28, no. 12, pp. 2009-2017, 2007.

[34] L. A. Greene and A. S. Tischler, "Establishment of a noradrenergic clonal line of rat adrenal pheochromocytoma cells which respond to nerve growth factor," Proceedings of the National Academy of Sciences of the United States of America, vol. 73, no. 7, pp. 2424-2428, 1976.

[35] B. Liu, P. Yang, Y. Ye et al., "Role of ROS in the protective effect of silibinin on sodium nitroprusside-induced apoptosis in rat pheochromocytoma PC12 cells," Free Radical Research, vol. 45, no. 7, pp. 835-847, 2011.

[36] Z. Kawakami, H. Kanno, Y. Ikarashi, and Y. Kase, "Yokukansan, a kampo medicine, protects against glutamate cytotoxicity due to oxidative stress in PC12 cells," Journal of Ethnopharmacology, vol. 134, no. 1, pp. 74-81, 2011.

[37] S. Ma, H. Liu, H. Jiao et al., "Neuroprotective effect of ginkgolide $\mathrm{K}$ on glutamate-induced cytotoxicity in PC 12 cells via inhibition of ROS generation and $\mathrm{Ca}^{2+}$ influx," NeuroToxicology, vol. 33, no. 1, pp. 59-69, 2012.

[38] J. Y. Jung, C. R. Han, Y. J. Jeong et al., "Epigallocatechin gallate inhibits nitric oxide-induced apoptosis in rat PC12 cells," Neuroscience Letters, vol. 411, no. 3, pp. 222-227, 2007.

[39] D. T. Loo, J. I. Fuquay, C. L. Rawson, and D. W. Barnes, "Extended culture of mouse embryo cells without senescence: inhibition by serum," Science, vol. 236, no. 4798, pp. 200-202, 1987.

[40] H. Yamaguchi, J. Zhu, T. Yu et al., "Serum-free mouse embryo cells generate a self-sustaining feedback loop for an astrocyte marker protein and respond to cytokines and bisphenol $\mathrm{A}$ in accordance with the subtle difference in their differentiation state," Cell Biology International, vol. 31, no. 6, pp. 638-644, 2007.

[41] J. Ye, Y. Li, T. Hamasaki et al., "Inhibitory effect of electrolyzed reduced water on tumor angiogenesis," Biological and Pharmaceutical Bulletin, vol. 31, no. 1, pp. 19-26, 2008.

[42] E. Ruoslahti, E. G. Hayman, M. Pierschbacher, and E. Engvall, "Fibronectin: purification, immunochemical properties, and biological activities," Methods in Enzymology, vol. 82, part A, pp. 803-831, 1982.

[43] R. A. Tobey, "Effects of cytosine arabinoside, daunomycin, mithramycin, azacytidine, adriamycin, and camptothecin on mammalian cell cycle traverse," Cancer Research, vol. 32, no. 12, pp. 2720-2725, 1972.

[44] N. K. Blank, F. J. Seil, and R. M. Herndon, "An ultrastructural study of cortical remodeling in cytosine arabinoside induced granuloprival cerebellum in tissue culture," Neuroscience, vol. 7, no. 6, pp. 1509-1531, 1982.

[45] Y. Oyama, A. Hayashi, T. Ueha, and K. Maekawa, "Characterization of 21,7/-dichlorofluorescin fluorescence in dissociated mammalian brain neurons: estimation on intracellular content of hydrogen peroxide," Brain Research, vol. 635, no. 1-2, pp. 113117, 1994.

[46] H. Kojima, M. Hirotani, N. Nakatsubo et al., "Bioimaging of nitric oxide with fluorescent indicators based on the rhodamine chromophore," Analytical Chemistry, vol. 73, no. 9, pp. 19671973, 2001.

[47] P. A. Vandenberghe and J. L. Ceuppens, "Flow cytometric measurement of cytoplasmic free calcium in human peripheral blood T lymphocytes with fluo-3, a new fluorescent calcium indicator," Journal of Immunological Methods, vol. 127, no. 2, pp. 197-205, 1990.
[48] M.-J. Kim, K. H. Jung, Y. K. Uhm, K.-H. Leem, and H. K. Kim, "Preservative effect of electrolyzed reduced water on pancreatic $\beta$-cell mass in diabetic $d b / d b$ mice," Biological and Pharmaceutical Bulletin, vol. 30, no. 2, pp. 234-236, 2007.

[49] A. Akaike, H. Katsuki, T. Kume, and T. Maeda, "Reactive oxygen species in NMDA receptor-mediated glutamate neurotoxicity," Parkinsonism \& Related Disorders, vol. 5, no. 4, pp. 203-207, 1999.

[50] C. Ghosh and D. K. Lahiri, "Increased vulnerability of neuronal cell lines to sodium nitroprusside-mediated toxicity is caused by the decreased level of nitric oxide metabolites," Journal of Molecular Neuroscience, vol. 13, no. 1-2, pp. 77-92, 1999.

[51] E. R. Whittemore, D. T. Loo, J. A. Watt, and C. W. Cotmans, "A detailed analysis of hydrogen peroxide-induced cell death in primary neuronal culture," Neuroscience, vol. 67, no. 4, pp. 921932, 1995.

[52] F. Mailly, P. Marin, M. Israël, J. Glowinski, and J. Prémont, "Increase in external glutamate and NMDA receptor activation contribute to $\mathrm{H}_{2} \mathrm{O}_{2}$-induced neuronal apoptosis," Journal of Neurochemistry, vol. 73, no. 3, pp. 1181-1188, 1999.

[53] S. Shirahata, T. Hamasaki, K. Haramaki et al., "Anti-diabetes effect of water containing hydrogen molecule and Pt nanoparticles," BMC Proceedings, vol. 5, supplement 8, pp. 18-20, 2011.

[54] K. Miyashita, M. Yasuda, T. Ota, and T. Suzuki, "Antioxidative activity of a cathodic solution produced by the electrolysis of a dilute $\mathrm{NaCl}$ solution," Bioscience, Biotechnology and Biochemistry, vol. 63, no. 2, pp. 421-423, 1999.

[55] K. Hanaoka, "Antioxidant effects of reduced water produced by electrolysis of sodium chloride solutions," Journal of Applied Electrochemistry, vol. 31, no. 12, pp. 1307-1313, 2001.

[56] T. Yanagihara, K. Arai, K. Miyamae et al., "Electrolyzed hydrogen-saturated water for drinking use elicits an antioxidative effect: a feeding test with rats," Bioscience, Biotechnology and Biochemistry, vol. 69, no. 10, pp. 1985-1987, 2005.

[57] A. Hiraoka, M. Takemoto, T. Suzuki et al., "Studies on the properties and real existence of aqueous solution systems that are assumed to have antioxidant activities by the action of "active hydrogen"', Journal of Health Science, vol. 50, no. 5, pp. 456-465, 2004.

[58] A. Hiraoka, S. Sasaki, T. Yamada, A. Shinohara, and M. Chibab, "Effects of drinking a water product with anti-oxidant activities in vitro on the blood levels of biomarker substances for the oxidative stress," Journal of Health Science, vol. 52, no. 6, pp. 817820, 2006.

[59] K. Fujita, T. Seike, N. Yutsudo et al., "Hydrogen in drinking water reduces dopaminergic neuronal loss in the 1-methyl-4phenyl-1,2,3,6-tetrahydropyridine mouse model of Parkinson's disease," PLoS ONE, vol. 4, no. 9, Article ID e7247, 2009.

[60] I. Ohsawa, M. Ishikawa, K. Takahashi et al., "Hydrogen acts as a therapeutic antioxidant by selectively reducing cytotoxic oxygen radicals," Nature Medicine, vol. 13, no. 6, pp. 688-694, 2007.

[61] S. Spulber, K. Edoff, L. Hong, S. Morisawa, S. Shirahata, and S. Ceccatelli, "Molecular hydrogen reduces lps-induced neuroinflammation and promotes recovery from sickness behaviour in mice," PLoS ONE, vol. 7, no. 7, Article ID e42078, 12 pages, 2012.

[62] T. Hamasaki, T. Kashiwagi, T. Imada et al., "Kinetic analysis of superoxide anion radical-scavenging and hydroxyl radicalscavenging activities of platinum nanoparticles," Langmuir, vol. 24, no. 14, pp. 7354-7364, 2008.

[63] M. Kajita, K. Hikosaka, M. Iitsuka, A. Kanayama, N. Toshima, and Y. Miyamoto, "Platinum nanoparticle is a useful scavenger 
of superoxide anion and hydrogen peroxide," Free Radical Research, vol. 41, no. 6, pp. 615-626, 2007.

[64] J. Kim, M. Takahashi, T. Shimizu et al., "Effects of a potent antioxidant, platinum nanoparticle, on the lifespan of Caenorhabditis elegans," Mechanisms of Ageing and Development, vol. 129, no. 6, pp. 322-331, 2008.

[65] Y. Yoshihisa, Q.-L. Zhao, M. A. Hassan et al., "SOD/catalase mimetic platinum nanoparticles inhibit heat-induced apoptosis in human lymphoma U937 and HH cells," Free Radical Research, vol. 45, no. 3, pp. 326-335, 2011.

[66] Y. Isobe, M. Yamauchi, R. Ikeda, and H. Kitagawa, "A study on hydrogen adsorption of polymer protected Pt nanoparticles," Synthetic Metals, vol. 135-136, pp. 757-758, 2003.

[67] J. Pelka, H. Gehrke, M. Esselen et al., "Cellular uptake of platinum nanoparticles in human colon carcinoma cells and their impact on cellular redox systems and DNA integrity," Chemical Research in Toxicology, vol. 22, no. 4, pp. 649-659, 2009.

[68] H. Gehrke, J. Pelka, C. G. Hartinger et al., "Platinum nanoparticles and their cellular uptake and DNA platination at noncytotoxic concentrations," Archives of Toxicology, vol. 85, no. 7, pp. 799-812, 2011.

[69] S. Krol, "Challenges in drug delivery to the brain: nature is against us," Journal of Controlled Release, vol. 164, no. 2, pp. 145155, 2012.

[70] S. Wohlfart, S. Gelperina, and J. Kreuter, "Transport of drugs across the blood-brain barrier by nanoparticles," Journal of Controlled Release, vol. 161, no. 2, pp. 264-273, 2012.

[71] R. R. Arvizo, S. Bhattacharyya, R. A. Kudgus, K. Giri, R. Bhattacharya, and P. Mukherjee, "Intrinsic therapeutic applications of noble metal nanoparticles: past, present and future," Chemical Society Reviews, vol. 41, no. 7, pp. 2943-2970, 2012.

[72] T. Satoh, Y. Enokido, H. Aoshima et al., "Changes in mitochondrial membrane potential during oxidative stress-induced apoptosis in PC12 cells," Journal of Neuroscience Research, vol. 50, pp. 413-420, 1997.

[73] Y. Zhang and B. R. Bhavnani, "Glutamate-induced apoptosis in neuronal cells is mediated via caspase-dependent and independent mechanisms involving calpain and caspase-3 proteases as well as apoptosis inducing factor (AIF) and this process is inhibited by equine estrogens," BMC Neuroscience, vol. 7, article 49, 2006.

[74] M. L. Circu and T. Y. Aw, "Reactive oxygen species, cellular redox systems, and apoptosis," Free Radical Biology and Medicine, vol. 48, no. 6, pp. 749-762, 2010.

[75] M. S. Ola, M. Nawaz, and H. Ahsan, "Role of Bcl-2 family proteins and caspases in the regulation of apoptosis," Molecular and Cellular Biochemistry, vol. 351, no. 1-2, pp. 41-58, 2011.

[76] K. Sinha, J. Das, P. B. Pal, and P. C. Sil, "Oxidative stress: the mitochondria-dependent and mitochondria-independent pathways of apoptosis," Archives of Toxicology, vol. 87, no. 7, pp. 1157-1180, 2013.

[77] R. J. Mailloux, X. Jin, and W. G. Willmore, "Redox regulation of mitochondrial function with emphasis on cysteine oxidation reactions," Redox Biology, vol. 2, no. 1, pp. 123-139, 2014.

[78] Y. Yang, B. Li, C. Liu et al., "Hydrogen-rich saline protects immunocytes from radiation-induced apoptosis," Medical Science Monitor, vol. 18, no. 4, pp. BR144-BR148, 2012.

[79] S. Kato, Y. Saitoh, K. Iwai, and N. Miwa, "Hydrogen-rich electrolyzed warm water represses wrinkle formation against UVA ray together with type-I collagen production and oxidativestress diminishment in fibroblasts and cell-injury prevention in keratinocytes," Journal of Photochemistry and Photobiology B: Biology, vol. 106, no. 1, pp. 24-33, 2012.

[80] M. Takamiya, Y. Miyamoto, T. Yamashita, K. Deguchi, Y. Ohta, and K. Abe, "Strong neuroprotection with a novel platinum nanoparticle against ischemic stroke- and tissue plasminogen activator-related brain damages in mice," Neuroscience, vol. 221, pp. 47-55, 2012.

[81] H. Nakanishi, T. Hamasaki, T. Kinjo et al., "Low concentration platinum nanoparticles effectively scavenge reactive oxygen species in rat skeletal L6 cells," Nano Biomedicine and Engineering, vol. 5, no. 2, pp. 76-85, 2013.

[82] V. Calabrese, E. Guagliano, M. Sapienza et al., "Redox regulation of cellular stress response in aging and neurodegenerative disorders: role of vitagenes," Neurochemical Research, vol. 32, no. 4-5, pp. 757-773, 2007.

[83] V. Calabrese, C. Cornelius, S. Cuzzocrea, I. Iavicoli, E. Rizzarelli, and E. J. Calabrese, "Hormesis, cellular stress response and vitagenes as critical determinants in aging and longevity," Molecular Aspects of Medicine, vol. 32, no. 4-6, pp. 279-304, 2011.

[84] V. Calabrese, C. Cornelius, A. T. Dinkova-Kostova et al., "Cellular stress responses, hormetic phytochemicals and vitagenes in aging and longevity," Biochimica et Biophysica Acta, vol. 1822, no. 5, pp. 753-783, 2012.

[85] C. Cornelius, R. Perrotta, A. Graziano, E. J. Calabrese, and V. Calabrese, "Stress responses, vitagenes and hormesis as critical determinants in aging and longevity: mitochondria as a 'chi', Immunity and Ageing, vol. 10, no. 1, article 15, 2013.

[86] C. Cornelius, A. Trovato Salinaro, M. Scuto et al., "Cellular stress response, sirtuins and UCP proteins in Alzheimer disease: role of vitagenes," Immunity and Ageing, vol. 10, no. 1, article 41, 2013.

[87] A. T. Salinaro, C. Cornelius, and G. Koverech, "Cellular stress response, redoxstatus, and vitagenes in glaucoma: a systemic oxidant disorder linked to Alzheimers disease," Experimental Pharmacology and Drug Discovery, vol. 5, article 129, pp. 1-8, 2014. 


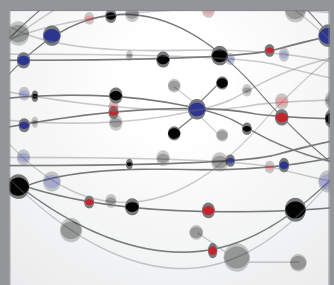

The Scientific World Journal
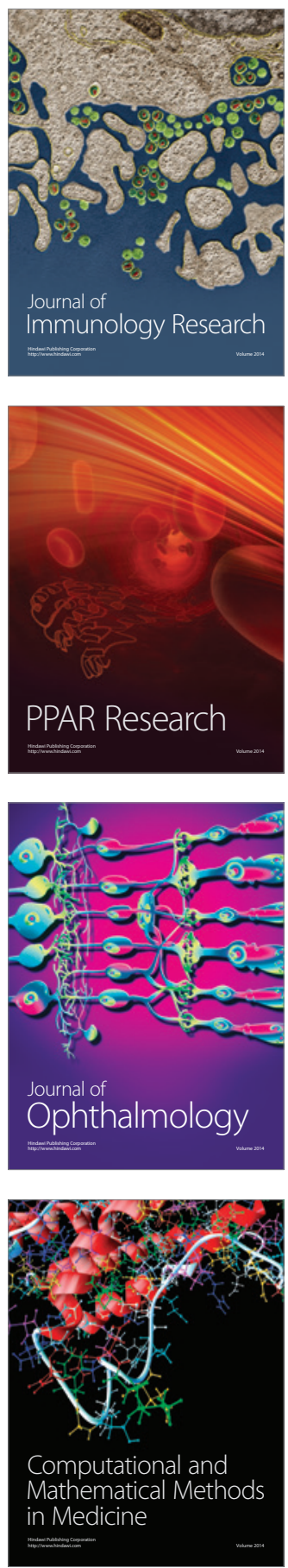

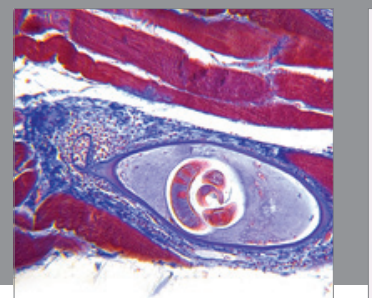

Gastroenterology

Research and Practice
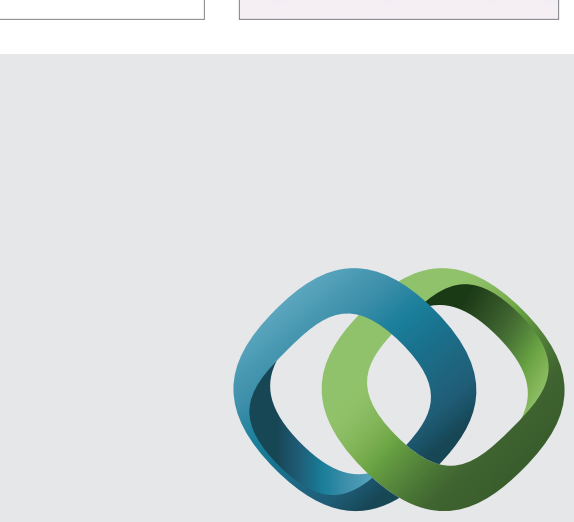

\section{Hindawi}

Submit your manuscripts at

http://www.hindawi.com
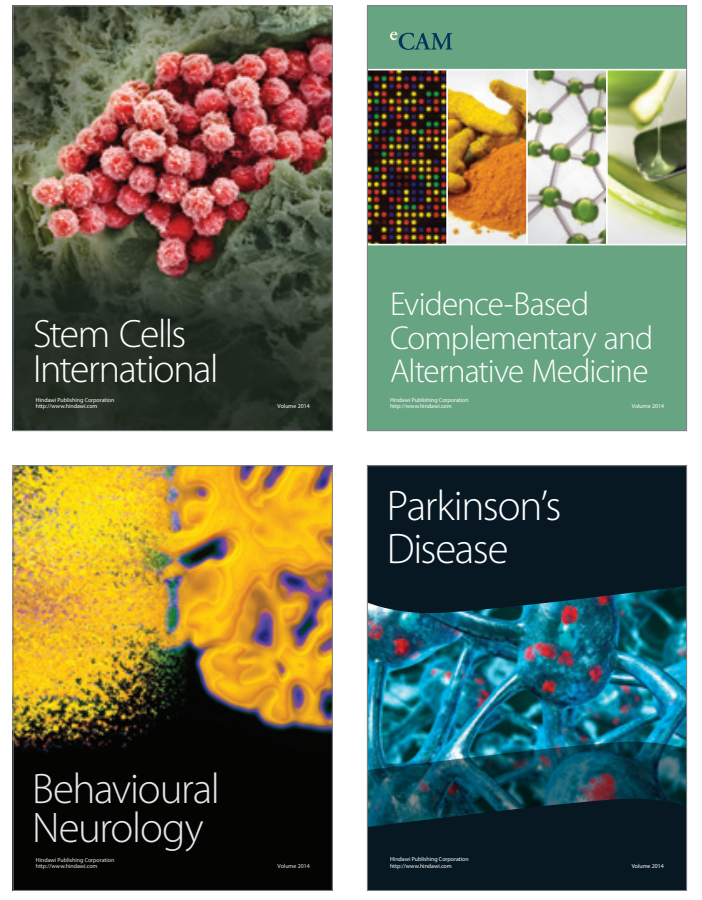
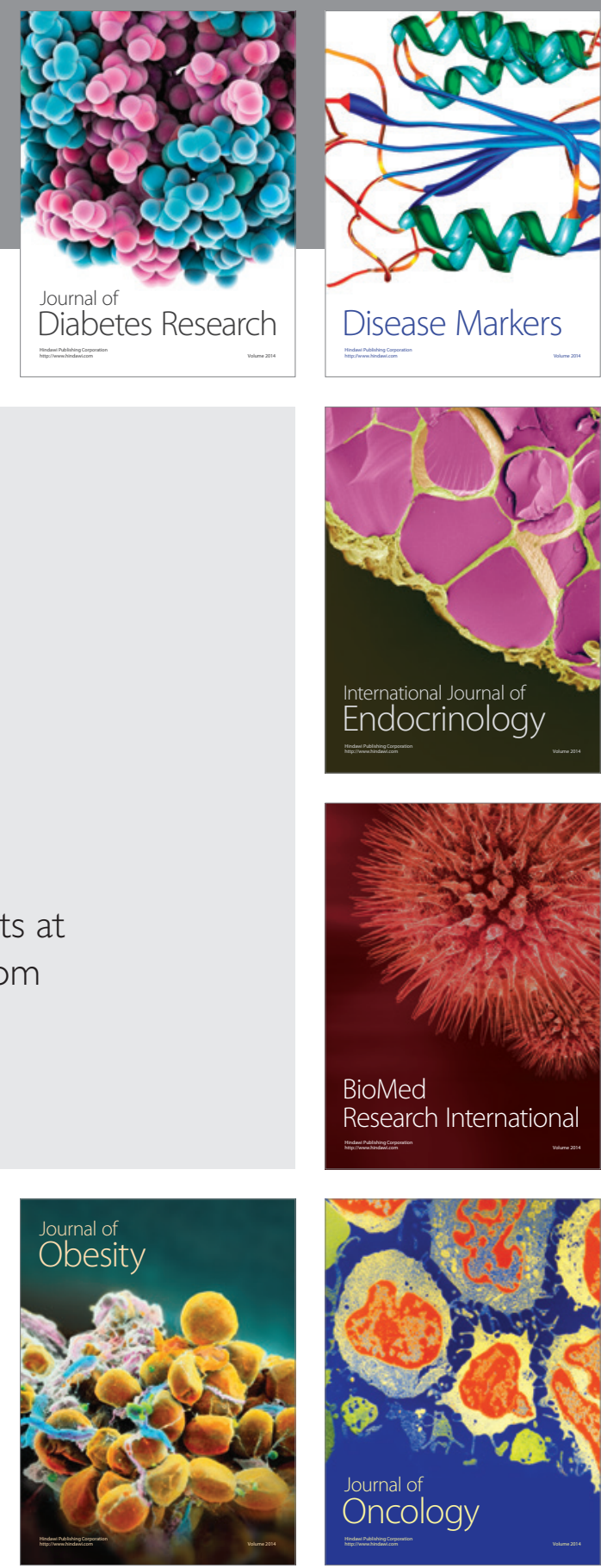

Disease Markers
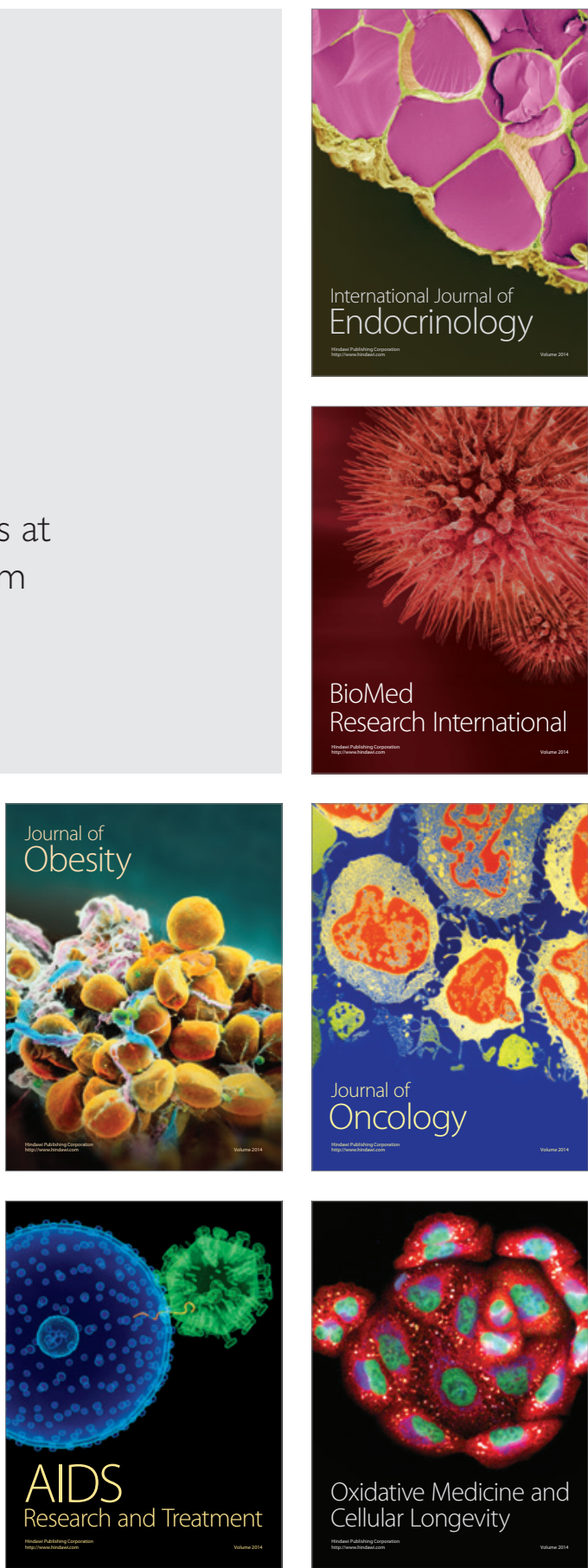